\title{
VOLUME E GRANULOMETRIA DO SUBSTRATO NA FORMAÇÃO DE MUDAS DE CAFÉ
}

\author{
JÚLIO EDUARdo TAVARES JÚNIOR
}

\author{
Dissertação apresentada à Escola Superior de \\ Agricultura "Luiz de Queiroz", Universidade de São \\ Paulo, para obtenção do título de Mestre em \\ Agronomia, Área de Concentração: Fitotecnia.
}

\author{
P I R A C I C A B A \\ Estado de São Paulo - Brasil \\ Janeiro - 2004
}




\title{
VOLUME E GRANULOMETRIA DO SUBSTRATO NA FORMAÇÃO DE MUDAS DE CAFÉ
}

\author{
JÚLIO EdUARdo TAVARES JÚNIOR
}

Engenheiro Agrônomo

Orientador: Prof. Dr. JOSÉ LAÉRCIO FAVARIN

Dissertação apresentada à Escola Superior de Agricultura "Luiz de Queiroz", Universidade de São

Paulo, para obtenção do título de Mestre em Agronomia, Área de Concentração: Fitotecnia.

\author{
P I R A C I C A B A \\ Estado de São Paulo - Brasil \\ Janeiro - 2004
}




\section{Dados Internacionais de Catalogação na Publicação (CIP)}

DIVISÃO DE BIBLIOTECA E DOCUMENTAÇÃO - ESALQ/USP

Tavares Júnior, Júlio Eduardo Volume e granulometria do substrato na formação de mudas de café / Júlio Eduardo Tavares Júnior. - - Piracicaba, 2004.

59 p.

Dissertação (mestrado) - - Escola Superior de Agricultura Luiz de Queiroz, 2004.

Bibliografia.

1. Café 2. Granulometria 3. Mudas 4. Substrato de cultura 5. Viveiros I. Título

CDD 633.73

"Permitida a cópia total ou parcial deste documento, desde que citada a fonte - O autor" 
Aos meus pais, Júlio Eduardo Tavares e

Romilda Gaion Tavares, por todo esforço

e luta para formar os filhos,

OFEREÇO

À minha esposa Ana Gláucia Camilo

Tavares, pelo amor, amizade e

companheirismo em todos os

momentos dessa jornada,

DEDICO 


\section{AGRADECIMENTOS}

Ao Professor Dr. José Laércio Favarin, pela orientação, confiança, oportunidade, amizade e companheirismo nos momentos difíceis.

Ao Pesquisador Cientifico Dr. Luiz Carlos Fazuoli, pela oportunidade, pelos ensinamentos e aprendizado, pelas sugestões, correções, críticas sinceras e importantes durante todos os anos de convivência e pela amizade.

Ao Prof. Dr. Durval Dourado Neto, pela oportunidade, confiança e amizade.

Ao Prof. Dr. Godofredo César Vitti, pelo estágio de graduação, pelos ensinamentos acadêmicos e de vida, e pela amizade.

À Prof ${ }^{a}$. Dra. Sônia Maria de Stefano Piedade, pelo auxílio nas análises estatísticas.

À Escola Superior de Agricultura "Luiz de Queiroz" - Universidade de São Paulo, e ao Instituto Agronômico de Campinas, pela oportunidade.

À CAPES pela concessão de bolsa de estudos.

À FAPESP, pelo financiamento do software SIARCs.

Aos funcionários e professores do Departamento de Produção Vegetal da ESALQ/USP, pelo convívio e respeito, e em especial, ao Celestino Alves Ferreira - "Tino" e a Silvia Borghesi pela ajuda irrestrita sempre que necessário. 
Aos funcionários, pesquisadores e extencionistas do Centro de Café "Alcides Carvalho" - IAC pela amizade e ajuda na condução do experimento, em especial aos colegas Engenheiros Agrônomos Roberto Antônio Thomaziello e Dr. José Ricardo Macedo Pezzopane.

Aos colegas Engenheiros Agrônomos Edson Tavares da Silva, Marco Perroni, Hélio Moraes de Siqueira Júnior, André Fontana, Rodrigo Lacerda, Salvador Olívio, Ernesto Vicentini, Romeu Ribeiro Franco Júnior, Marcelo Reis e tantos outros que de várias maneiras contribuíram para o meu conhecimento técnico e formação profissional.

À amiga Renata Mariano pela colaboração na normatização dessa dissertação.

Aos colegas Engenheiros Agrônomos Luciano Henrique Barbosa Teixeira e Evelin Krebsy pela ajuda na correção ortográfica dessa dissertação.

Ao Engenheiro Agrônomo, Dr Fábio Prata, amigo de todas as horas, por todo o apoio e auxílio antes, durante e após a conclusão do curso.

À todos os amigos que de alguma maneira contribuíram para a realização desse trabalho, durante o transcorrer desse curso e em todas as etapas da minha vida. 


\section{SUMÁRIO}

\begin{tabular}{|c|c|}
\hline LISTA DE FIGURAS......... & $\begin{array}{r}\text { Página } \\
\text { vii }\end{array}$ \\
\hline LISTA DE TABELAS... & viii \\
\hline RESUMO........ & $\mathrm{x}$ \\
\hline SUMMARY .............. & xii \\
\hline 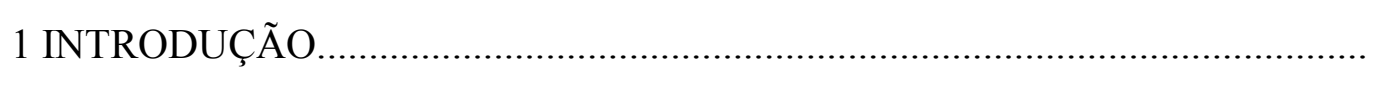 & 1 \\
\hline 2 REVISÃO DE LITERATURA........ & 4 \\
\hline 3 MATERIAL E MÉTODOS & 14 \\
\hline 3.1 Número de pares de folhas............................... & 23 \\
\hline 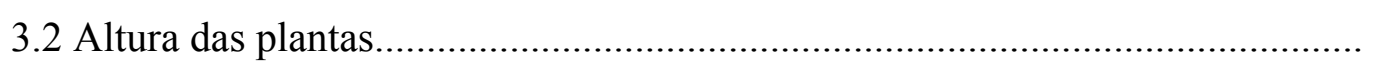 & 23 \\
\hline 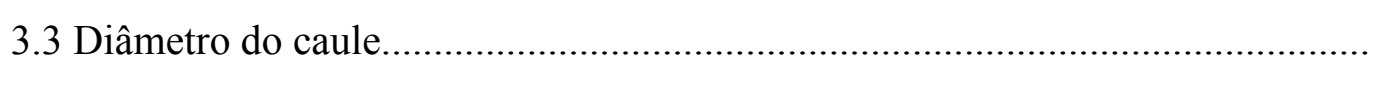 & 24 \\
\hline 3.4 Matéria seca da parte aérea e das raízes........... & 24 \\
\hline 3.5 Área foliar total da planta................. & 24 \\
\hline 3.6 Área foliar média....... & 24 \\
\hline 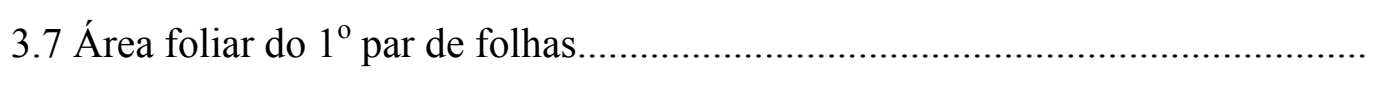 & 24 \\
\hline 3.8 Comprimento e superfície de raízes.................. & 25 \\
\hline 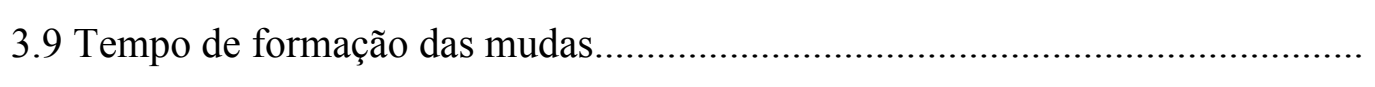 & 25 \\
\hline 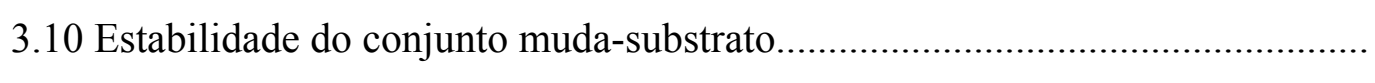 & 25 \\
\hline 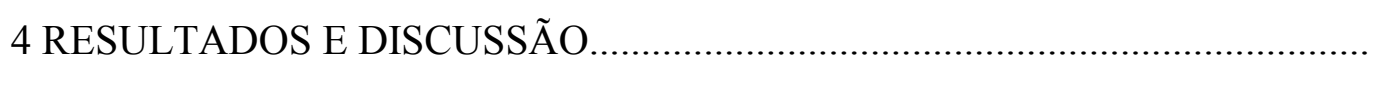 & 26 \\
\hline 5 CONCLUSÕES & 50 \\
\hline 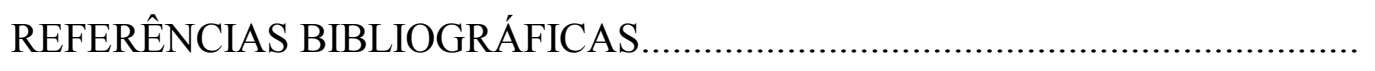 & 51 \\
\hline
\end{tabular}




\section{LISTA DE FIGURAS}

1 Detalhe da estrutura do viveiro onde foram apoiadas as bandejas com as mudas

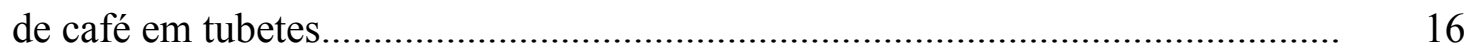

2 Tubetes com capacidade para 50, 120 e $200 \mathrm{~cm}^{3}$ de substrato utilizados no experimento

3 Crescimento vegetativo das mudas de café formadas com 50, 120 e $200 \mathrm{~cm}^{3}$ de substrato.

4 Massa de material desagregado do conjunto muda-substrato ao final de cada ciclo de 60" de vibração em razão do volume de substrato.

5 Massa de material desagregado do conjunto muda-substrato ao final de cada ciclo de 60 "' de vibração em razão da granulometria do substrato........................ 


\section{LISTA DE TABELAS}

1 Tratamentos com base no volume e na granulometria do material em razão das composições granulométricas a partir do substrato comercial plantmax............

2 Quantidade de material retido ( $\mathrm{g}$ ) nas diferentes peneiras, em razão da composição granulométrica do substrato comercial na granulometria original (100\% SC), substrato comercial finamente moído (100\% SCM) e pela

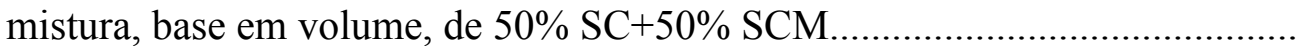

3 Atributos físicos do substrato como capacidade de água disponível (CAD), densidade aparente e condutividade elétrica, em razão da composição granulométrica do substrato

4 Teores de nutrientes, matéria orgânica e pH conforme a composição granulométrica do substrato.

5 Quantidades de nutrientes fornecidas às plantas de café pela adição do

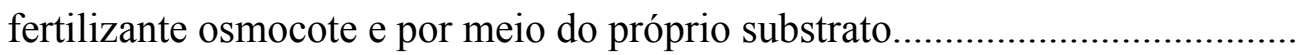

6 Médias do número de pares de folhas das mudas de café em razão do volume $\left(50,120\right.$ e $\left.200 \mathrm{~cm}^{3}\right)$ e granulometria do substrato $(100 \% \mathrm{SC}, 100 \% \mathrm{SCM}$ e $50 \% \mathrm{SC}+50 \% \mathrm{SCM})$

7 Tempo de formação (meses) da muda de café em razão do volume e granulometria do substrato.

8 Médias da altura (cm) das mudas de café em razão do volume (50, 120 e 200 $\mathrm{cm}^{3}$ ) de substrato.

9 Médias do diâmetro do caule $(\mathrm{mm})$ das mudas de café em razão do volume $\left(50,120\right.$ e $\left.200 \mathrm{~cm}^{3}\right)$ e da granulometria do substrato $(100 \% \mathrm{SC}, 100 \% \mathrm{SCM}$ e $50 \% \mathrm{SC}+50 \% \mathrm{SCM})$ 
10 Médias do diâmetro do caule $(\mathrm{mm})$ das mudas de café em razão da interação entre as variáveis volume e granulometria do substrato.

11 Médias da matéria seca da parte aérea e das raízes ( $\mathrm{g}$ ) das mudas de café em razão do volume $\left(50,120\right.$ e $\left.200 \mathrm{~cm}^{3}\right)$ e da granulometria do substrato $(100 \% \mathrm{SC}, 100 \% \mathrm{SCM}$ e $50 \% \mathrm{SC}+50 \% \mathrm{SCM})$

12 Médias da área foliar total $\left(\mathrm{cm}^{2}\right)$, área foliar média $\left(\mathrm{cm}^{2}\right)$ e área foliar do $1^{\mathrm{o}}$ par de folhas $\left(\mathrm{cm}^{2}\right)$ das mudas de café em razão do volume $(50,120$ e 200 $\left.\mathrm{cm}^{3}\right)$ e da granulometria do substrato $(100 \% \mathrm{SC}, 100 \% \mathrm{SCM}$ e $50 \% \mathrm{SC}+$ $50 \% \mathrm{SCM})$

13 Concentração de nutrientes na folhas das plantas de café em razão dos tratamentos.

14 Médias da área foliar total $\left(\mathrm{cm}^{2}\right)$ das mudas de café em razão da interação entre as variáveis volume e granulometria do substrato................................

15 Médias do comprimento de raízes $(\mathrm{m})$ e da superfície de raízes $\left(\mathrm{cm}^{2}\right)$ das mudas de café em razão do volume $\left(50,120\right.$ e $\left.200 \mathrm{~cm}^{3}\right)$ e da granulometria do substrato $(100 \% \mathrm{SC}, 100 \% \mathrm{SCM}$ e $50 \% \mathrm{SC}+50 \% \mathrm{SCM})$

16 Médias da massa de material desagregado (g) do conjunto muda-substrato ao final de cada ciclo de 60" de vibração em razão do volume de substrato........

17 Médias da massa de material desagregado (g) do conjunto muda-substrato ao final de cada ciclo de 60" de vibração em razão da granulometria do substrato

18 Médias da massa de material desagregado ( $\mathrm{g}$ ) do conjunto muda-substrato ao final do $3^{\circ}$ ciclo de $60 "$ de vibração em razão da interação das variáveis volume e granulometria do substrato. 


\title{
VOLUME E GRANULOMETRIA DO SUBSTRATO NA FORMAÇÃO DE MUDAS DE CAFÉ
}

\author{
Autor: JÚLIO EDUARDO TAVARES JÚNIOR \\ Orientador: Prof. Dr. JOSÉ LAÉRCIO FAVARIN
}

\section{RESUMO}

Este trabalho foi realizado com o objetivo de avaliar a influência do volume e da granulometria do substrato comercial, utilizado na produção de mudas em tubetes, sobre o crescimento vegetativo das plantas de café, bem como o tempo de formação das mudas e a estabilidade ao manuseio do conjunto muda-substrato. O experimento foi conduzido no viveiro do Centro de Café do IAC, localizado na Fazenda Santa Elisa, Campinas, SP, utilizando a cultivar Catuaí Vermelho IAC 144 (Coffea arabica L.). Foram adotados nove tratamentos com quatro repetições, com delineamento de blocos ao acaso em esquema fatorial 3 x 3, formado pela combinação de três volumes de substrato $\left(50,120\right.$ e $\left.200 \mathrm{~cm}^{3}\right)$ e três granulometrias proporcionadas pelas seguintes composições granulométricas: $100 \%$ de substrato comercial na granulometria original, $100 \%$ de substrato comercial finamente moído e pela mistura, em volume, de $50 \%$ de substrato na granulometria comercial com 50\% de substrato moído. A influência das variáveis (volume e granulometria) do substrato no crescimento das mudas de café foi avaliada por meio das determinações dos parâmetros biométricos vegetativo da parte aérea e raízes como: número de pares de folhas, altura da planta, diâmetro do caule, matéria seca da parte aérea e das raízes, área foliar total, área foliar média, área do $1^{\circ}$ par de folhas, comprimento e superfície de raízes. Em complemento aos objetivos do 
trabalho foram, também, avaliados o tempo de formação das mudas e a estabilidade ao manuseio do conjunto muda-substrato. $\mathrm{O}$ crescimento das plantas depende do volume $\mathrm{e}$ da granulometria do substrato, sendo maior com a utilização de $200 \mathrm{~cm}^{3}$ de substrato e a diminuição da granulometria pela mistura, em partes iguais, do substrato finamente moído com o substrato comercial na granulometria original. O tempo de formação das mudas correlacionou com o volume de substrato, demandando 134, 124 e 81 dias para a emissão do $4^{\circ}$ par de folhas, quando as plantas cresceram nos recipientes com 50,120 e $200 \mathrm{~cm}^{3}$ de substrato, respectivamente. A estabilidade ao manuseio do conjunto mudasubstrato varia com o tamanho do recipiente, sendo maior nos tubetes com 50 e $120 \mathrm{~cm}^{3}$ de substrato, e a redução parcial da granulometria, pela mistura granulométrica, aumentou a aderência das partículas com as raízes e, portanto, a estabilidade do conjunto. 


\title{
SUBSTRATE VOLUME AND GRANULOMETER IN COFFEE SEEDLINGS PRODUCTION
}

\author{
Author: JÚLIO EDUARDO TAVARES JÚNIOR \\ Adviser: Prof. Dr. JOSÉ LAÉRCIO FAVARIN
}

\section{SUMMARY}

The objectives of this research are the evaluation of substrate volume and granulometer influence - used in production of coffee seedlings in plastic tubes - on coffee plants growth, the time of seedlings development and also seedling-substrate handling stability. The investigation was carried out in a nursery at Coffee Experimental Center of IAC, SP, Brazil, with the cultivar Catuaí Vermelho IAC 144 (Coffea arabica L.). Nine treatments were tested with 4 replicates and the experimental design used was randomized blocks with $3 \times 3$ factorial composed by 3 substrate volumes (50, 120 and $200 \mathrm{~cm}^{3}$ ) and 3 granulometer substrate levels obtained by the following granulometer compositions: $100 \%$ of substrate on original granulometer, $100 \%$ of crushed substrate and the mix, in volume, of $50 \%$ of substrate on original granulometer and $50 \%$ of crushed substrate. The substrate volume and granulometer influence on coffee seedlings growth was evaluated by determination of growth parameters of shoot and root as: number of leaves, seedling height, stem diameter, root and shoot dry matter, total leaf area, average leaf area, first leaf area, root length and surface. In addition to these parameters, the time of seedlings development and seedling-substrate handling stability were also investigated. The seedlings growth depend on substrate volume and granulometer, being higher when $200 \mathrm{~cm}^{3}$ of substrate volume are used keeping an equal 
proportion of the different substrate granulometers (original and crushed). The time of seedlings growth did show a correlation with the substrate volume demanding 134, 124 and 81 days for developing the $4^{\text {th }}$ leaf pair when the plants developed in 50,120 and $200 \mathrm{~cm}^{3}$ of substrate, respectivelly. The seedling-substrate handling stability differs with recipient size, while the granulometer reduction increases the seedling-substrate stability. 


\section{INTRODUÇÃO}

A importância econômica e social da cafeicultura nacional pode ser avaliada por vários indicadores como a receita cambial anual de 4 bilhões de dólares, área plantada equivalente a 2,3 milhões de hectares e por gerar, somente no Estado de São Paulo, aproximadamente, 5 milhões de empregos diretos (Agrianual, 2003).

$\mathrm{Na}$ cafeicultura é contínua a demanda por mudas de café em razão das ampliações da área de plantio e pela necessidade da substituição de lavouras velhas. As inovações técnicas como o aumento da densidade de plantas por hectare e o plantio de novas cultivares, adequadas à cafeicultura moderna com plantas de porte baixo, resistentes a doenças e tolerantes a nematóides, justificam a renovação das lavouras antigas.

As reformas e as implantações de lavouras de café têm sido efetuadas, principalmente, por meio de mudas produzidas em recipientes plástico de $7 \mathrm{~cm}$ de diâmetro por $20 \mathrm{~cm}$ de altura $\left(615 \mathrm{~cm}^{3}\right)$, preenchidos com substrato formado pela mistura de terra argilosa de subsolo com esterco curtido, enriquecido com fertilizantes minerais. Este método de produção apresenta algumas desvantagens, podendo-se destacar o consumo de grande volume de material e a necessidade de expurgo para evitar a disseminação de nematóides e plantas daninhas.

Uma inovação técnica que vem sendo assimilada pelo setor cafeeiro, na área de produção de mudas, é a utilização de tubetes e substratos alternativos. A adoção desta tecnologia reduz a demanda por mão-de-obra e espaço para a instalação do viveiro, assim com de a quantidade de substratos, pois os recipientes utilizados com esta finalidade possuem menor capacidade volumétrica $\left(120 \mathrm{~cm}^{3}\right)$ em relação ao recipiente tradicional. 
A maioria dos trabalhos realizados com substratos comerciais na formação de mudas de café enfoca, predominantemente, os atributos químicos do material como a dose a ser aplicada e composição em nutrientes, a solubilidade da fonte e o tempo de liberação dos nutrientes (Oliveira et al., 1995; Paiva et al., 1997; Paiva et al., 1998; Favoreto et al., 1998; Guimarães et al., 1998; Ortolani et al., 1998; Melo et al., 1999b; Melo et al., 1999c; Melo et al., 1999d).

A granulometria do material é um atributo físico muito importante que influência a aeração às raízes, entretanto não tem sido avaliada nos trabalhos dessa natureza. Pode-se admitir, por hipótese, que a aderência entre as partículas do substrato com as raízes é dependente da textura do material. Essa característica é fundamental à manutenção da integridade do conjunto muda-substrato e à preservação da sua estabilidade após a retirada do tubete e o manuseio durante o transplantio. Tal fato é desejável, pois as raízes de café são muito frágeis por serem pouco lignificadas no momento do plantio e, portanto, são susceptíveis aos danos mecânicos, podendo sofrer rupturas e ou enovelamentos.

No sistema convencional de formação de mudas a mistura de terra argilosa com esterco curtido resulta num substrato com partículas coesas e aderência suficiente destas com as raízes das plantas, conferindo, resistência do torrão à deformação após a retirada do recipiente plástico no momento do plantio. Desta maneira, as plantas não ficam com as raízes nuas e expostas às pressões nesta fase, preservando a sua disposição nos espaços porosos do substrato e, com isso, são pouco danificadas. Em conseqüência, a intensidade do estresse sofrido pelas plantas recém transplantadas é menor, favorecendo o pegamento das mudas e, dessa maneira, reduz-se a necessidade de replantio, bem como antecipa o reinício do crescimento das plantas no campo.

A falta de experiência da mão-de-obra e a necessidade de maior cuidado no manuseio da muda formada em tubete é, em parte, responsável pelos casos de insucessos do plantio. Observações de campo e levantamentos preliminares indicam que há necessidade de estudos para avaliar a influência dos atributos físicos do substrato, principalmente àquele relacionado com o esboroamento. 
Neste trabalho assumiu, por hipótese, que a redução da granulometria em razão da composição granulométrica do substrato poderá aumentar a adesão das partículas com as raízes das plantas e, em conseqüência, a resistência do conjunto muda-substrato, característica fundamental à preservação da sua estabilidade após a retirada do tubete e o manuseio durante o plantio no campo. Com o aumento da estabilidade do conjunto muda-substrato seria preservada a integridade do sistema radicular e, assim, diminuiria o risco de deformação e danos às raízes no plantio. Do exposto, poder-se-ia esperar que as mudas seriam menos prejudicadas, favorecendo, portanto, o estabelecimento e a retomada do crescimento das plantas num período menor, após a implantação no campo.

Este trabalho foi realizado com o objetivo de avaliar a influência do volume e da granulometria do substrato comercial, utilizado na produção de mudas em tubetes, sobre o crescimento vegetativo das plantas de café, bem como o tempo de formação das mudas e a estabilidade, ao manuseio, do conjunto muda-substrato. 


\section{REVISÃO DE LITERATURA}

O método convencional de formação de mudas de café em relação à produção em tubetes apresenta inúmeras desvantagens, como o risco de disseminação de plantas daninhas e de infecções por nematóides, sendo indispensável o expurgo da mistura por defensivo prejudicial ao ambiente, além do que a demanda por espaço à instalação do viveiro e o número de mão-de-obra, que em todas as fases de produção, é muito superior (Paiva et al., 1998; Melo et al., 1999a).

No referido método é utilizado recipiente plástico com capacidade para $615 \mathrm{~cm}^{3}$ de substrato, propiciando às plantas maior volume de material e espaço para o crescimento das raízes. Neste aspecto, as condições oferecidas às plantas quando são conduzidas em tubetes, recipiente empregado para uso de substrato comercial, com capacidade para $120 \mathrm{~cm}^{3}$ de substrato, tanto a quantidade de material quanto o espaço às raízes são bem inferiores. Além disto, o uso de tubetes inviabiliza o uso do substrato padrão, obtido pela mistura de terra argilosa de subsolo com esterco curtido, pois nestes recipientes a consistência dura do material, pelo predomínio de substâncias minerais em sua composição, compromete a renovação do ar e a atividade das raízes e, por extensão, o crescimento vegetativo das mudas de café (Favarin \& Camargo, 1999).

Os recipientes empregados na produção de mudas devem impedir o enovelamento das raízes, serem resistentes para não se desintegrarem na fase de formação no viveiro e, principalmente, durante o transporte. Precisam, também, permitir que o conjunto recipiente-substrato proporcione condições necessárias ao crescimento das plantas e à sua nutrição mineral, que protejam as raízes dos danos mecânicos e da desidratação, possibilitando a máxima sobrevivência e crescimento vegetativo depois do transplantio (Campinhos Júnior \& Ikemori, 1983). A forma do recipiente deve ser 
uniforme, de fácil manuseio na fase de viveiro, no transporte da muda até o campo e durante a operação de plantio.

Os recipientes de plástico são ainda os mais utilizados na produção de mudas de café, embora apresentem inúmeros inconvenientes operacionais como as dificuldades para o seu enchimento, encanteiramento, carregamento, transporte até o campo, distribuição na lavoura, bem como demanda grandes volumes de substratos, além dos elevados riscos de infecções das plantas e de infestações diversas da área agrícola (Campinhos Júnior \& Ikemori, 1983). Durante o manuseio do conjunto muda-substrato é comum ocorrer o dobramento do recipiente plástico, que implica na perda da estabilidade do referido conjunto, devido a falta de compactação do material no preenchimento do recipiente, provocando ruptura das raízes das plantas antes e durante o plantio.

Segundo Costa et al. (1993) a utilização de tubete induz o desenvolvimento descendente das raízes do cafeeiro, sem os problemas de enovelamento das mesmas como ocorre no recipiente convencional. Ressalta-se que durante o transplantio das plântulas, no estádio de folhas cotiledonares envoltas pelo endocarpo ("palito de fósforo") ou de folhas cotiledonares expandidas ("orelha de onça"), deve-se evitar o dobramento da raiz principal, uma vez que este problema não poderá ser eliminado no momento do plantio das mudas no campo, pois a deformação ocorre logo abaixo do colo da planta.

De acordo com Simões (1987) a utilização de tubetes na produção de mudas de essências florestais apresenta algumas vantagens, entre as quais a formação do sistema radicular sem enovelamento na extremidade inferior, rápido crescimento das plantas após o plantio e maiores facilidades operacionais durante o manejo no viveiro. Para Favoreto et al. (1992) os tubetes substituem, com vantagens, os recipientes tradicionais na formação de mudas de café, pois seu formato cônico afunilado e aberto na extremidade inferior drena eficientemente o excesso de água e bloqueia o crescimento das raízes pela luz e o ar circundante na saída do recipiente. As pequenas estrias longitudinais na forma de pequenas arestas em direção ao interior do tubete serve para 
direcionar o crescimento das raízes no sentido descendente, impedindo o enovelamento lateral das mesmas, como ocorre comumente no recipiente tradicional de plástico.

Em estudo desenvolvido por Mello (1989) para avaliar o tamanho e o tipo do recipiente no crescimento das plantas de eucaliptus, o pesquisador comparou tubete de $50 \mathrm{~cm}^{3}$ com recipiente plástico de $200 \mathrm{~cm}^{3}$. De acordo com o autor, não houve diferença na sobrevivência das plantas e tampouco sobre o crescimento da parte aérea e das raízes. Em trabalho semelhante, realizado com mudas de café, Melo et al. (1999a) avaliaram o crescimento das plantas em tubetes com 50 e $120 \mathrm{~cm}^{3}$ de substrato e, segundo os autores, também não foi constatada diferença na formação da planta na fase de viveiro. Esta constatação é surpreendente, considerando a grande diferença na quantidade de substrato, de espaço às raízes e nutrientes às plantas, em razão do volume de material utilizado.

No sistema convencional de produção de mudas de café em recipiente plástico, é utilizado um substrato constituído pela mistura de 700 litros de terra de subsolo argilosa com 300 litros de esterco curtido, enriquecida pelo fornecimento de $5 \mathrm{~kg}$ de superfosfato simples, $2,5 \mathrm{~kg}$ de cloreto de potássio e $0,5 \mathrm{~kg}$ de calcário dolomítico (Melo et al., 1999c; Thomaziello et al., 1996; Gonçalves \& Thomaziello, 1970). Como já discutido, a terra pode constituir-se em uma fonte de inóculos de nematóides e plantas daninhas, devendo ser, gradativamente, substituída por substratos alternativos, como por exemplo, os substratos comerciais, sem risco de contaminação e por isso, não dependem da desinfecção química.

Substrato é definido como um material ou mistura de materiais que são empregados para o desenvolvimento de mudas, podendo ser de origem animal, vegetal ou mineral, cujas funções consistem na sustentação da planta, retenção de água e fornecimento de nutrientes. Fundamentalmente, é constituído de uma parte sólida, à base de partículas minerais e orgânicas, em que estão presentes poros, ocupados por água, ar e raízes. O crescimento e a eficiência do sistema radicular é dependente da aeração do substrato, contribuindo para tal o tamanho das partículas, responsáveis pela sua textura (Sturion, 1981). 
Segundo Spurr \& Barnes (1973) o substrato exerce influência significativa na arquitetura do sistema radicular e no estado nutricional das plantas. As principais alterações nas raízes são provocadas pela qualidade e quantidade do substrato, em particular, quando é utilizado recipiente de menor volume. Nestas condições, a elevada concentração de raízes no recipiente, depende de suprimento adequado de oxigênio $\left(\mathrm{O}_{2}\right)$ para que a mesma não seja comprometida, assim como a remoção do dióxido de carbono $\left(\mathrm{CO}_{2}\right)$ do meio, que deve ser eficiente. Para o crescimento vegetal não ser afetado é indispensável que não haja limitação de água, o que implica em irrigações freqüentes, o que aumenta o risco de lixiviação de nutrientes e de ocorrer encharcamentos temporários, provocando, inevitavelmente, estresses às plantas. Assim, as características do material adotado na produção de mudas podem afetar a qualidade da planta em formação, avaliadas por parâmetros biométricos relacionados ao crescimento vegetal (Walters et al., 1970).

Coutinho \& Carvalho (1983) definem como substrato ideal àquele que possui baixa densidade específica, é rico em nutrientes, tem composição física e química uniforme, apresenta elevada capacidade de troca catiônica, adequada retenção de água, drenagem e aeração. Além disso, a coesão entre as partículas deve ser suficiente, bem como a aderência com as raízes e não se constituir em fonte de inóculos. Para Minami (1995) as principais características dos substratos são: (i) baixa densidade, (ii) elevada porosidade, (iii) isentos de contaminantes fitopatogênicos, (iv) elevada capacidade de retenção de água, (v) quantidade de sais solúveis que não prejudique o desenvolvimento das raízes, (vi) nutrientes em quantidade suficiente para o bom desenvolvimento das mudas e (vii) baixo custo por unidade. Dificilmente todas estas características estão presentes em um único composto, tendo-se que misturar vários materiais com atributos diferentes para que se obtenha tais qualidades. De acordo com as descrições apresentadas por estes autores, constata-se que os requisitos de um substrato para a formação de mudas não são claramente definidos, permanecendo, ainda, no campo das generalidades, fato que dificulta a análise e interpretação sobre os atributos determinantes da sua qualidade. 
De acordo com Minami (1995) o substrato é o componente mais sensível e complexo do sistema de produção de mudas, uma vez que qualquer variação na sua composição pode alterar o processo de formação da planta, reduzindo, acentuadamente, a germinação da semente e, até mesmo, o crescimento vegetativo das plantas.

Phipps (1974) estudou a influência do meio sobre o crescimento das mudas de essências florestais produzidas em tubetes e concluiu que a composição do substrato pode afetar tanto o crescimento quanto a sobrevivência das plantas, não sendo as diferenças atribuídas, exclusivamente, às características químicas do material. A partir da observação deste autor pode se afirmar que os atributos físicos dos substratos são tão importantes quanto os atributos químicos. Entretanto, a maioria dos trabalhos prioriza a avaliação dos atributos químicos do substrato em detrimento das características fisicas.

De acordo com Hartmann et al. (1981) o substrato deve apresentar uma relação adequada entre água e ar para suprir a necessidade da planta, uma vez que, devido ao pequeno volume do recipiente e, conseqüentemente, a pequena profundidade dos mesmos, são proporcionadas condições físicas diferentes daquelas encontradas nos diferentes tipos de solo. Assim, é fundamental que os atributos físicos favoreçam a aeração, a retenção de água e que a drenagem ocorra sem impedimentos, pois o sistema radicular da planta formada em recipiente contendo substrato alternativo é confinado num volume muito restrito, explorado por um período, relativamente, longo. Portanto, o cuidado com a drenagem e o suprimento de oxigênio é imprescindível para o desenvolvimento das raízes e, por extensão, da própria planta.

A capacidade de retenção de água é um dos atributos físicos mais importantes dos substratos, determinada através da curva de retenção de água (De Boodt \& Verdonck, 1972), utilizando tensões iguais a 10, 50 e $100 \mathrm{~cm}$, inferiores às tensões utilizadas em solos. A condução de plantas em recipientes e casa de vegetação ocorre em condições de umidade elevada comparativamente àquela, normalmente, verificada no campo (Verdonck, 1983). De acordo com Beardsell et al. (1979), a água disponível para as plantas conduzidas em substratos é superior à maioria dos solos agrícolas, o que explica a necessidade de irrigações freqüentes quando o material é constituído tendo 
como base a terra, em razão da sua menor capacidade de retenção de água (Boyle et al., 1991).

Gomes et al. (1985) estudaram diferentes substratos e misturas de materiais na formação de mudas de eucaliptus em tubete e concluíram que o composto obtido com a mistura de substância orgânica (80\%) e moinha de carvão (20\%) apresentaram maior estabilidade entre o substrato e o sistema radicular das mudas. Dantas (1992) recomenda para a produção de mudas de eucaliptus em tubetes a inclusão na mistura, de um composto de carvão na proporção de 80:20, uma vez que o mesmo acelera o crescimento das plantas e aumenta a agregação entre as raízes e o composto (aderência).

Francescato (1995) avaliou a influência de diferentes substratos na formação de porta-enxerto cítrico de limão cravo em tubete, como o plantmax, rendmax, citri 1, citri 2, e uma mistura à base de casca de pinus moída com vermiculita. De acordo com o autor os melhores resultados para a formação das mudas foram obtidos com a utilização de substratos comerciais, não havendo diferença entre os mesmos.

A maioria dos trabalhos sobre a produção de mudas em tubetes com a utilização de substratos alternativos foi realizada, principalmente, nas culturas de pinus e eucaliptus, plantas olerícolas e também em frutíferas como citrus e maracujá (Guimarães et al., 1998). Entretanto, a produção de mudas de café em tubetes com substrato alternativo, comercializado como plantmax, é uma técnica que vem sendo utilizada de maneira crescente pelo setor cafeeiro.

O substrato comercializado como plantmax é constituído pela mistura de vermiculita expandida, casca de pinus, turfa e perlita, enriquecido com nutrientes minerais por meio de fonte de solubilidade gradual como o osmocote, com a finalidade de atender a demanda da planta na fase de viveiro, sem risco de deficiência pelas perdas por lixiviação. Este substrato é isento de patógenos e de propágulos de plantas daninhas, dispensando a aplicação de defensivo para expurgá-lo (Favoreto et al., 1992; Melo et al., 1999c).

Segundo Douglas (1987) a vermiculita é um mineral de argila do tipo 2:1, constituída por duas lâminas tetraédricas de sílica envolvendo uma lâmina octaédrica de alumina, ferro e magnésio, com estrutura variável, encontrada em depósitos de 
ocorrência natural em várias partes do mundo. Figueira (2000) relata que a inclusão de vermiculita expandida na composição do substrato aumentou a sua capacidade de retenção de água, pois este mineral micáceo absorve até cinco vezes o seu volume em água. Além disso, contém potássio e magnésio disponíveis e, também, possui elevada capacidade de troca de cátions.

A casca de Pinus é um subproduto da atividade florestal brasileira destinada a produção de papéis e celulose. As cascas de árvores são moídas e compostadas, apresentando partículas de tamanhos variáveis, constituídas por celulose e outros carboidratos similares sendo, portanto, um material orgânico que se decompõe com o tempo. Entre as suas principais características destacam-se a elevada capacidade de troca de cátions, boa drenagem, baixa capacidade de absorção de água e pH ácido, com índice igual a 3,7 (Gonçalves, 1995).

De acordo com Resh (1995) e Gonçalves (1995) a turfa consiste em vegetação aquática e pantanosa, parcialmente decomposta. A turfa preta resulta de material altamente decomposto e apresenta $\mathrm{pH}$ entre 4,1 a 5,3, com elevado poder tampão. Este material contém cerca de 70 a $85 \%$ de matéria orgânica e, apresenta, aproximadamente, $1 \%$ de N, traços de P e K, aeração deficiente, elevada capacidade de retenção de água e relação $\mathrm{C} / \mathrm{N}$ variável entre 9 a 37:1.

A perlita é um material silícico de origem vulcânica extraído dos rios de lava, é formada por partículas estéreis muito leves que apresentam grande capacidade de retenção de água, absorvendo cerca de três a quatro vezes o seu peso em água, $\mathrm{pH}$ entre 6 e 8, não tem capacidade de troca de cátions e também não contém nutrientes na forma disponível às plantas (Matinez \& Barbosa, 1999). Este material moído e peneirado é aquecido a $760^{\circ} \mathrm{C}$, provocando a evaporação da água residual e a expansão das suas partículas.

Vários trabalhos foram realizados com o intuito de avaliar os substratos alternativos para a formação de mudas de café. Entretanto, estes estudos enfocam, predominantemente, os atributos químicos do material como a dose a ser aplicada e composição em nutrientes, a solubilidade do fertilizante e o tempo de sua liberação (Oliveira et al., 1995; Paiva et al., 1997; Paiva et al., 1998; Favoreto et al., 1998; 
Guimarães et al., 1998; Ortolani et al., 1998; Melo et al., 1999b; Melo et al., 1999c; Melo et al., 1999d). Os resultados obtidos evidenciam que estes materiais apresentam desempenho superior ou semelhante à mistura de terra argilosa de subsolo com esterco curtido, além de proporcionarem a redução do custo de produção por unidade (Melo et al., 1999b; Favarin \& Camargo, 1999; Ortolani et al., 1998; Andrade Neto et al., 1997). As mudas de café formadas com uma mistura composta por $60 \%$ de material orgânico, $20 \%$ de vermiculita e $20 \%$ de terra argilosa de subsolo, propiciaram um crescimento superior em relação as plantas produzidas somente com o substrato comercial plantmax (Melo et al. 1999d).

A granulometria do material é um atributo físico muito importante que influencia a aeração às raízes, entretanto não tem sido avaliada nos trabalhos dessa natureza. Pode-se admitir, por hipótese, que a aderência entre as partículas do substrato com as raízes é dependente da finura do material. Esta característica é fundamental à manutenção da integridade do conjunto muda-substrato e à preservação da sua estabilidade, após a retirada do tubete e o manuseio durante o transplantio. Tal fato é desejável, pois as raízes de café são muito frágeis por serem pouco lignificadas no momento do plantio e, portanto, são susceptíveis aos danos mecânicos, podendo sofrer rupturas e ou enovelamentos.

Entre os problemas verificados no plantio de mudas de café formada em tubete com substrato alternativo, comercializado como plantmax, destaca-se a maior dificuldade operacional que, em algumas situações, compromete, substancialmente, o estabelecimento da planta no campo, comparativamente ao método convencional em que é utilizado recipiente plástico contendo uma mistura de terra argilosa de subsolo com esterco curtido.

No sistema convencional de formação de mudas a mistura de terra argilosa com esterco curtido resulta num substrato com partículas coesas e aderência suficiente destas com as raízes das plantas, conferindo resistência do torrão à deformação após a retirada do recipiente plástico no momento do plantio. Desta maneira, as plantas não ficam com as raízes nuas e expostas às pressões nesta fase, preservando a sua disposição nos espaços porosos do substrato e, com isso, são pouco danificadas. Em conseqüência, 
a intensidade do estresse sofrido pelas plantas recém transplantadas é menor, favorecendo o pegamento das mudas e, dessa maneira, reduz-se a necessidade de replantio, bem como antecipa o reinício do crescimento das plantas no campo.

A falta de experiência da mão-de-obra e a necessidade de maior cuidado no manuseio da muda formada em tubete é, em parte, responsável pelos casos de insucessos do plantio. Observações de campo e levantamentos preliminares indicam que há necessidade de estudos para avaliar a influência dos atributos físicos do substrato, principalmente àqueles relacionados com o esboroamento.

Neste trabalho assumiu, por hipótese, que a redução da granulometria em razão da composição granulométrica do substrato poderá aumentar a adesão das partículas com as raízes das plantas e, em conseqüência, a resistência do conjunto muda-substrato, característica fundamental à preservação da sua estabilidade após a retirada do tubete e o manuseio durante o plantio no campo. Com o aumento da estabilidade do conjunto muda-substrato seria preservada a integridade do sistema radicular e, assim, diminuiria o risco de deformação e danos às raízes no plantio. Do exposto, poderia-se esperar que as mudas seriam menos prejudicadas, favorecendo, portanto, o estabelecimento e a retomada do crescimento das plantas num período menor após a implantação no campo. De acordo com Thomaziello ${ }^{1}$ os produtores de mudas e os cafeicultores de algumas regiões do Estado de São Paulo questionam a eficiência e a qualidade das mudas de café formadas em tubetes, uma vez que esta técnica demanda mão-de-obra capacitada para o plantio, bem como requer maior disponibilidade hídrica para o pegamento e estabelecimento das plantas. Tais constatações reforçam a hipótese sobre a importância dos atributos físicos do substrato, em particular, da granulometria, como forma de aumentar a estabilidade do conjunto muda-substrato, visando a integridade das raízes durante o plantio, com o intuito de diminuir o risco de deformação e danos às mesmas, prejudicando o estabelecimento e retardando a retomada do crescimento das plantas no campo.

Este trabalho foi realizado com o objetivo de avaliar a influência do volume e da granulometria do substrato comercial, utilizado na produção de mudas em tubetes,

\footnotetext{
${ }^{1}$ THOMAZIELLO, R. A. Comunicação pessoal, 2002.
} 
sobre o crescimento vegetativo das plantas de café, bem como o tempo de formação das mudas e a estabilidade, ao manuseio, do conjunto muda-substrato. 


\section{MATERIAL E MÉTODOS}

O experimento foi instalado no viveiro de mudas do Centro de Café e Plantas Tropicais do Instituto Agronômico de Campinas, localizado na Fazenda Santa Elisa, em Campinas, SP.

Foram utilizadas sementes de café da cultivar Catuaí Vermelho IAC 144, as quais foram semeadas na proporção de $1 \mathrm{~kg} \mathrm{~m}^{-2}$ em germinadores de areia. As plântulas foram transplantadas para os tubetes quando atingiram o estádio de folhas cotiledonares expandidas ("orelha de onça"), conforme recomendações do IBC (1986).

As plântulas no estádio "orelha de onça" foram retiradas dos germinadores e colocadas em recipientes com água para evitar o murchamento até o efetivo transplantio. Esta operação foi realizada de maneira criteriosa para não provocar danos às raízes, utilizando plantas com desenvolvimento semelhante. Após a retirada do terço final da raiz principal, para evitar o enovelamento, as mesmas foram colocadas em orifícios abertos no substrato, procedendo a uma leve compressão do substrato, visando a eliminação dos espaços vazios ao redor das raízes e a fixação da planta no tubete (Oliveira et al., 1995; Paiva et al., 1997).

O viveiro utilizado para a condução do experimento é do tipo cobertura alta e o controle da insolação foi realizado com tela sombrite. Após o transplante das plântulas nos tubetes, as mesmas permaneceram durante trinta dias no "viveiro berçário" com $50 \%$ de insolação, em turnos de regas de duas horas e duração de cinco minutos, das 8:00 às 18:00 horas, perfazendo cinco irrigações diárias. Ao final desse período, as mudas já apresentavam o $1^{0}$ par de folhas expandidas, momento em que foram transferidas para ambiente com $70 \%$ de insolação, em turno de regas de três horas e 
duração de cinco minutos, das 9:00 às 18:00 horas, totalizando três irrigações diárias. Neste ambiente as mudas foram conduzidas até o final do experimento.

Para a irrigação foi utilizado o sistema de micro aspersão com aspersores do tipo NAAN, vazão nominal de $60 \mathrm{~L} \mathrm{~h}^{-1}$ e diâmetro molhado de $7 \mathrm{~m}$. Os aspersores foram colocados a $1 \mathrm{~m}$ de altura, acima da base de apoio das bandejas de mudas e distribuídos a uma distância de 3 m entre os mesmos.

Os tubetes foram acondicionados em bandejas individuais de $47 \mathrm{~cm}$ de largura por $61 \mathrm{~cm}$ de comprimento, feitas de tela de arame ondulada de $3,5 \mathrm{~mm}$ de diâmetro e furos quadrados. Para os tubetes de $50 \mathrm{~cm}^{3}$ utilizou-se bandeja de orifícios quadrados de $30 \mathrm{~mm}$, dispondo de espaços para 750 tubetes por $\mathrm{m}^{2}$, alojandos-os em furos alternados, o que totalizou 360 mudas por $\mathrm{m}^{2}$. Para os tubetes de $120 \mathrm{~cm}^{3}$ as bandejas possuíam orifícios quadrados de $36 \mathrm{~mm}$, comportando espaços para 520 tubetes por $\mathrm{m}^{2}$, que também foram distribuídos em furos alternados, perfazendo 250 mudas por $\mathrm{m}^{2}$. As bandejas para o suporte dos tubetes de $200 \mathrm{~cm}^{3}$ possuíam furos quadrados de $60 \mathrm{~mm}$, com capacidade para alocar 256 tubetes por $\mathrm{m}^{2}$, os quais foram, igualmente, dispostos em furos alternados, num total de 130 tubetes por $\mathrm{m}^{2}$ (Figura 1). A disposição das mudas em lojas alternadas foi adotada para evitar que as plantas, com o crescimento, sofressem a concorrência por insolação. 


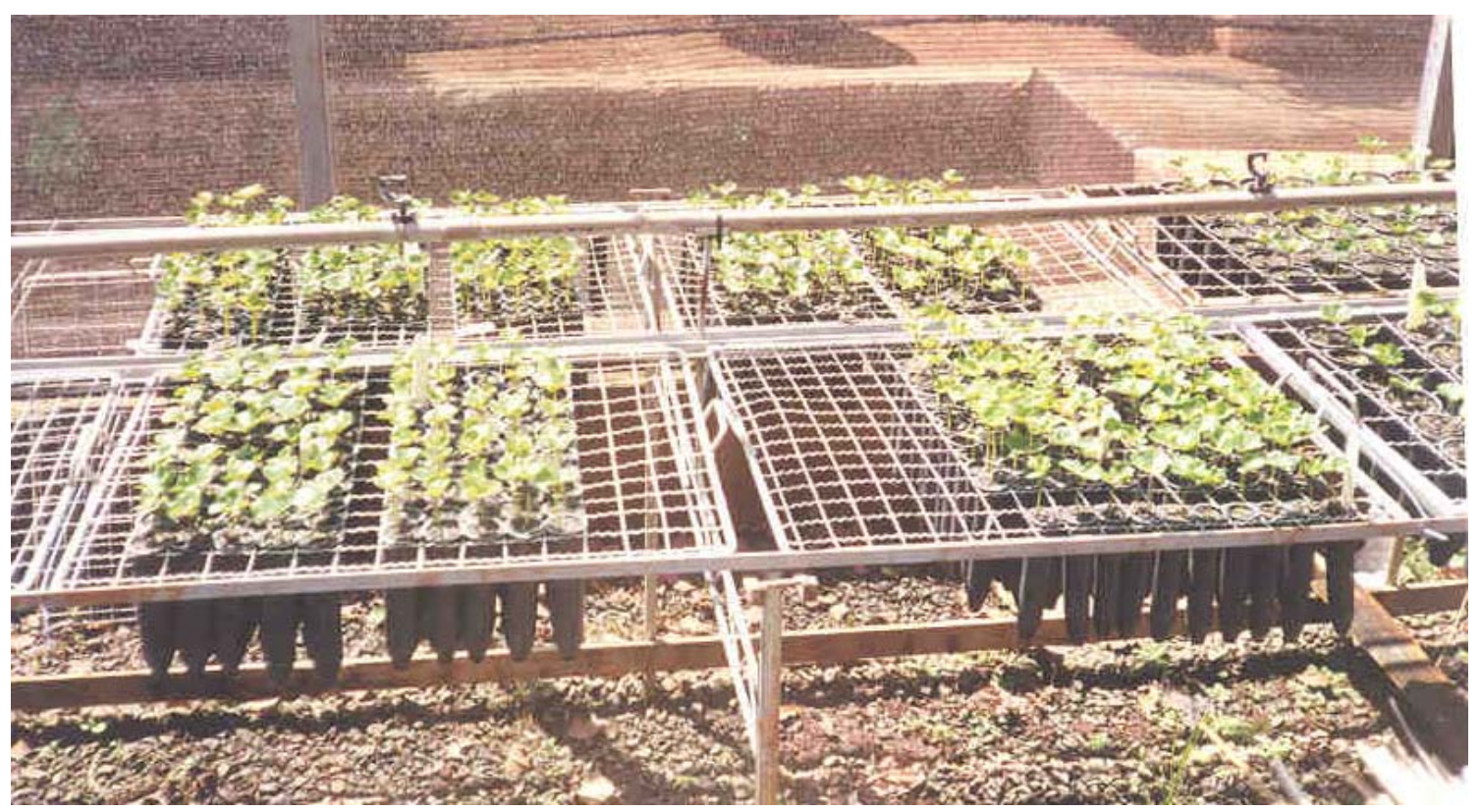

Figura 1 - Detalhe da estrutura do viveiro onde foram apoiadas as bandejas com as mudas de café em tubetes

Foi adotado o delineamento experimental de blocos ao acaso em esquema fatorial 3x3, obtido pela combinação de três volumes de substrato $\left(50,120\right.$ e $\left.200 \mathrm{~cm}^{3}\right)$ e três níveis para a granulometria, em razão das composições granulométricas a partir do substrato comercial - plantmax na granulometria original, perfazendo nove tratamentos (Tabela 1), com quatro repetições. Cada bloco representou uma repetição contendo nove parcelas, distribuídas aleatoriamente e constituídas por 50 plantas, das quais foram retiradas, ao acaso, 10 plantas para as determinações dos parâmetros biométricos, com a finalidade de avaliar o crescimento vegetal, tanto da parte aérea quanto das raízes. 
Tabela 1. Tratamentos com base no volume e na granulometria do material em razão das composições granulométricas a partir do substrato comercial plantmax

\begin{tabular}{ccc}
\hline Tratamentos & $\begin{array}{c}\text { Volume } \\
\left(\mathrm{cm}^{3}\right)\end{array}$ & $\begin{array}{c}\text { Composição granulométrica do substrato } \\
\text { V1G1 }\end{array}$ \\
V1G2 & 50 & $\begin{array}{l}100 \% \text { substrato comercial na granulometria original (SC) } \\
100 \% \text { substrato comercial finamente moído (SCM) }\end{array}$ \\
V1G3 & 50 & $50 \%$ substrato comercial (SC)+50\% substrato moído (SCM) \\
V2G1 & 120 & $100 \%$ substrato comercial na granulometria original (SC) \\
V2G2 & 120 & $100 \%$ substrato comercial finamente moído (SCM) \\
V2G3 & 120 & $50 \%$ substrato comercial (SC) $+50 \%$ substrato moído (SCM) \\
V3G1 & 200 & $100 \%$ substrato comercial na granulometria original (SC) \\
V3G2 & 200 & $100 \%$ substrato comercial finamente moído (SCM) \\
V3G3 & 200 & $50 \%$ substrato comercial (SC) $+50 \%$ substrato moído (SCM) \\
\hline
\end{tabular}

${ }^{1}$ mistura granulométrica com base em volume

O substrato alternativo utilizado é comercializado como plantmax, possuindo em sua composição turfa, perlita, vermiculita expandida e material vegetal compostado de casca de pinus e eucaliptus, de acordo com as informações de técnicos da empresa fabricante (Eucatex).

Nos tratamentos V1G1, V2G1 e V3G1 utilizou-se o substrato comercial plantmax na granulometria original (100\% SC), apresentando 30,84\% das partículas retidas nas peneiras $50(0,297 \mathrm{~mm})$ e $270(0,053 \mathrm{~mm})$ (Tabela 2). Nos tratamentos V1G2, V2G2 e V3G2 foi utilizado o mesmo substrato após ter sido finamente moído (100\% SCM), possuindo 62,24\% das partículas retidas nas peneiras $50(0,297 \mathrm{~mm}) \mathrm{e}$ $270(0,053 \mathrm{~mm})$, praticamente o dobro da quantidade destas partículas em relação a granulometria comercial (Tabela 2). Finalmente, os tratamentos V1G3, V2G3 e V3G3 foram constituídos pela mistura, com base em volume, de 50\% do substrato comercial na granulometria original (SC) e 50\% do substrato comercial finamente moído (SCM), contendo $49,83 \%$ das partículas retidas nas peneiras $50(0,297 \mathrm{~mm})$ e $270(0,053 \mathrm{~mm})$, 
situando-se, portanto, numa posição intermediária entre os tratamentos anteriores (Tabela 2).

Tabela 2. Quantidade de material retido (g) nas diferentes peneiras, em razão da composição granulométrica do substrato comercial na granulometria original (100\% SC), substrato comercial finamente moído (100\% SCM) e pela mistura, base em volume, de $50 \% \mathrm{SC}+50 \% \mathrm{SCM}$

\begin{tabular}{cccc}
\hline $\begin{array}{c}\text { Peneiras ABNT } \\
(\mathrm{mm})\end{array}$ & $\begin{array}{c}100 \% \text { Substrato } \\
\text { comercial (SC) }\end{array}$ & $\begin{array}{c}100 \% \text { Substrato moído } \\
(\mathrm{SCM})\end{array}$ & $\begin{array}{c}50 \% \mathrm{SC}+50 \% \\
\mathrm{SCM}\end{array}$ \\
\hline $6(3,36)$ & 9,22 & Gramas \\
$10(2,00)$ & 11,63 & 0,40 & 5,70 \\
$18(1,00)$ & 17,58 & 2,11 & 5,43 \\
$35(0,50)$ & 30,71 & 10,00 & 11,57 \\
$50(0,297)$ & 17,82 & 25,23 & 27,40 \\
$270(0,053)$ & 13,02 & 23,47 & 20,55 \\
\hline
\end{tabular}

O substrato comercial finamente moído (SCM) foi obtido pela moagem do substrato comercial em moinho de martelo, com o material macerado sendo pressionado contra uma peneira instalada na saída da máquina. As três composições granulométricas foram determinadas através de um conjunto de peneiras para a quantificação das diferentes frações de partículas (Ansorena Miner 1994).

A análise física para a determinação da capacidade de água disponível, densidade aparente e condutividade elétrica, foi realizada de acordo com a metodologia descrita por Ansorena Miner (1994), cujos resultados encontram-se na Tabela 3. A análise química para a determinação dos teores de nutrientes foi realizada conforme a metodologia descrita por Ansorena Miner (1994), cujos resultados estão apresentados na Tabela 4. 
Tabela 3. Atributos físicos do substrato como capacidade de água disponível (CAD), densidade aparente e condutividade elétrica, em razão da composição granulométrica do substrato

\begin{tabular}{cccc}
\hline $\begin{array}{c}\text { Composição } \\
\text { granulométrica }\end{array}$ & CAD & Densidade aparente & Condutividade elétrica \\
& $(\%)$ & $\left(\mathrm{g} \mathrm{cm}^{-3}\right)$ & $\left(\mathrm{dS} \mathrm{m}^{-2}\right)$ \\
\hline $100 \% \mathrm{SC}$ & 186,7 & 0,43 & 0,54 \\
$100 \% \mathrm{SCM}$ & 177,1 & 0,46 & 0,31 \\
$50 \% \mathrm{SC}+50 \% \mathrm{SCM}$ & 196,7 & 0,46 & 0,40 \\
\hline
\end{tabular}

As variações dos atributos físicos (Tabela 3) e dos teores de nutrientes e matéria orgânica (Tabela 4), verificadas em função das diferentes composições granulométricas, deve-se a heterogeneidade do próprio substrato e, provavelmente, à perda de materiais durante a moagem. 
Tabela 4. Teores de nutrientes, matéria orgânica e pH conforme a composição granulométrica do substrato

\begin{tabular}{|c|c|c|c|c|}
\hline \multirow{2}{*}{ Parâmetros } & \multirow{2}{*}{ Unidade } & \multicolumn{3}{|c|}{ Composição granulométrica do substrato } \\
\hline & & $100 \% \mathrm{SC}$ & $100 \% \mathrm{SCM}$ & $50 \% \mathrm{SC}+50 \% \mathrm{SCM}$ \\
\hline Potássio & & 54,36 & 40,77 & 46,21 \\
\hline Sódio & & 17,75 & 12,68 & 15,21 \\
\hline Fósforo & & 2,22 & 1,37 & 1,46 \\
\hline Cálcio & & 20,12 & 6,19 & 11,03 \\
\hline Magnésio & & 13,63 & 3,98 & 7,46 \\
\hline Enxofre & $\mathrm{mg} \mathrm{L}^{-1}$ & 69,77 & 33,66 & 48,55 \\
\hline Cobre & & 0,02 & 0,02 & 0,02 \\
\hline Ferro & & 0,56 & 0,99 & 0,70 \\
\hline Manganês & & 0,01 & 0,02 & 0,008 \\
\hline Zinco & & 0,04 & 0,03 & 0,02 \\
\hline Boro & & 0,54 & 0,51 & 0,53 \\
\hline M.O & $\mathrm{g} \mathrm{dm}^{-3}$ & 142 & 166 & 149 \\
\hline $\mathrm{pH}$ & & 4,80 & 4,90 & 4,90 \\
\hline
\end{tabular}

A escolha dos diferentes volumes de substratos foi feita com base no recipiente padrão em uso na formação de mudas de café $\left(120 \mathrm{~cm}^{3}\right)$, acrescentando tubete com capacidade inferior $\left(50 \mathrm{~cm}^{3}\right)$ e superior $\left(200 \mathrm{~cm}^{3}\right)$, conforme pode ser visualizados na Figura 2. 

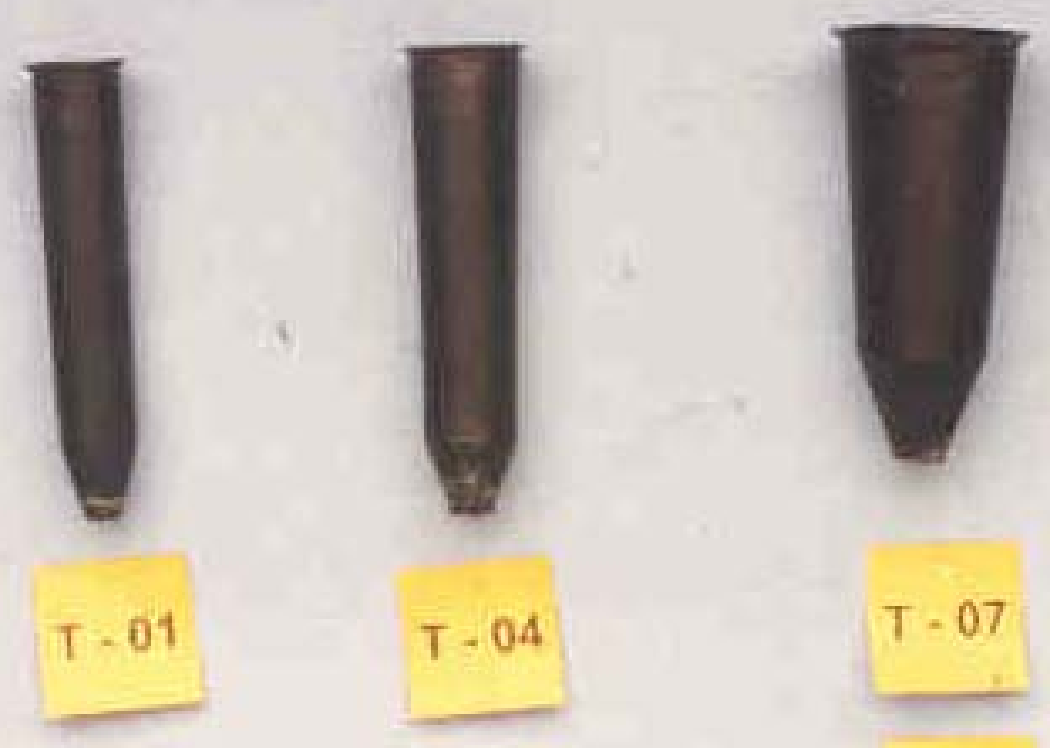

T. 02
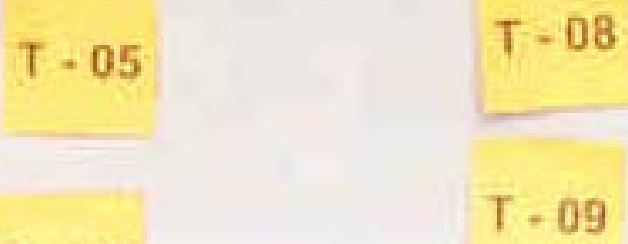

\section{$T-03$}

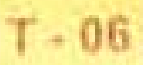

Figura 2 - Tubetes com capacidade para 50, 120 e $200 \mathrm{~cm}^{3}$ de substrato, utilizados no experimento

Para a fertilização do substrato comercial foram adotadas as recomendações de Paiva et al. (1998) e Melo et al. (1999c), utilizando osmocote na dose de $18 \mathrm{~g}$ por $\mathrm{kg}$ de substrato. O fertilizante continha 15: 10: $10\left(\%\right.$ de $\mathrm{N}, \mathrm{P}_{2} \mathrm{O}_{5}$ e $\left.\mathrm{K}_{2} \mathrm{O}\right)$, além de 3,5\% de Ca, $1,5 \%$ de $\mathrm{Mg}, 3,0 \%$ de $\mathrm{S}, 0,05 \%$ de $\mathrm{Zn}, 0,02 \%$ de $\mathrm{B}, 0,05 \%$ de $\mathrm{Cu}, 0,1 \%$ de $\mathrm{Mn}, 0,5 \%$ de Fe e $0,004 \%$ de Mo. O fertilizante osmocote tem como característica a liberação gradual dos nutrientes, que se dá no período de 5 a 6 meses após a sua aplicação, variando de acordo com a umidade e a temperatura do substrato. A quantidade total de nutrientes disponível às plantas por meio da adubação de base, fornecida por meio do fertilizante osmocote, e pelos nutrientes provenientes do próprio substrato é apresentada na Tabela 5. 
Para o enchimento dos tubetes procedeu-se o umedecimento do substrato, adicionando $240 \mathrm{ml}$ de água por quilograma de substrato e, posteriormente, a mistura foi homogeneizada juntamente com a dose do fertilizante osmocote. Na seqüência, colocouse o substrato nos tubetes apoiados em uma bandeja, que foi presa a uma mesa vibratória com a finalidade de uniformizar a compactação e o volume de substrato dos tubetes, conforme metodologia descrita por Favoreto et al. (1992).

Durante a condução do experimento foram efetuadas três adubações complementares, via fertirrigação, utilizando 2,0 g por litro de água do fertilizante 15:5:15 (\% de $\mathrm{N}, \mathrm{P}_{2} \mathrm{O}_{5}$ e $\mathrm{K}_{2} \mathrm{O}$ ), aplicado a cada 30 dias a partir do lançamento do terceiro par de folhas.

Para a avaliação da influência das variáveis volume e granulometria do substrato nos parâmetros biométricos de crescimento da parte aérea e das raízes das plantas foram feitas as seguintes determinações: (i) número de pares de folhas, (ii) altura das plantas, (iii) diâmetro do caule (iv) matéria seca da parte aérea e das raízes, (v) área foliar total, (vi) área foliar média, (vii) área foliar do $1^{\circ}$ par de folhas e (viii) comprimento $\mathrm{e}$ superfície de raízes. Em atendimento aos objetivos do trabalho foram determinados também: (ix) o tempo de formação das mudas e (x) a estabilidade, ao manuseio, do conjunto muda-substrato. 
Tabela 5. Quantidades de nutrientes fornecidas às plantas de café pela adição do fertilizante osmocote e por meio do próprio substrato

\begin{tabular}{cccccccccccc}
\hline Tratamentos & $\mathrm{N}^{(1)}$ & $\mathrm{P}$ & $\mathrm{K}$ & $\mathrm{Ca}$ & $\mathrm{Mg}$ & $\mathrm{S}$ & $\mathrm{B}$ & $\mathrm{Cu}$ & $\mathrm{Fe}$ & $\mathrm{Mn}$ & $\mathrm{Zn}$ \\
V1G1 & 0,06 & 0,15 & 2,76 & 1,02 & 0,69 & 3,50 & 27 & 1 & 30 & 1 & 2 \\
V1G2 & 0,06 & 0,17 & 2,14 & 0,34 & 0,21 & 1,72 & 26 & 2 & 55 & 2 & 2 \\
V1G3 & 0,06 & 0,24 & 2,48 & 0,61 & 0,40 & 2,48 & 27 & 2 & 43 & 2 & 2 \\
Média & $\mathbf{0 , 0 6}$ & $\mathbf{0 , 1 9}$ & $\mathbf{2 , 4 6}$ & $\mathbf{0 , 6 6}$ & $\mathbf{0 , 4 3}$ & $\mathbf{2 , 5 7}$ & $\mathbf{2 7}$ & $\mathbf{2}$ & $\mathbf{4 3}$ & $\mathbf{2}$ & $\mathbf{2}$ \\
V2G1 & 0,14 & 0,31 & 6,56 & 2,43 & 1,64 & 8,38 & 65 & 3 & 69 & 2 & 5 \\
V2G2 & 0,14 & 0,26 & 4,99 & 0,78 & 0,49 & 4,07 & 61 & 3 & 124 & 3 & 4 \\
V2G3 & 0,14 & 0,34 & 5,71 & 1,38 & 0,92 & 5,88 & 64 & 3 & 92 & 3 & 3 \\
Média & $\mathbf{0 , 1 4}$ & $\mathbf{0 , 3 0}$ & $\mathbf{5 , 7 5}$ & $\mathbf{1 , 5 3}$ & $\mathbf{1 , 0 0}$ & $\mathbf{6 , 1 1}$ & $\mathbf{6 3}$ & $\mathbf{3}$ & $\mathbf{9 5}$ & $\mathbf{3}$ & $\mathbf{4}$ \\
V3G1 & 0,25 & 0,49 & 10,91 & 4,04 & 2,73 & 13,97 & 108 & 4 & 114 & 2 & 8 \\
V3G2 & 0,25 & 0,37 & 8,25 & 1,27 & 0,81 & 6,77 & 102 & 5 & 203 & 5 & 7 \\
V3G3 & 0,25 & 0,46 & 9,41 & 2,26 & 1,52 & 9,76 & 106 & 5 & 148 & 3 & 5 \\
Média & $\mathbf{0 , 2 5}$ & $\mathbf{0 , 4 4}$ & $\mathbf{9 , 5 2}$ & $\mathbf{2 , 5 2}$ & $\mathbf{1 , 6 9}$ & $\mathbf{1 0 , 1 7}$ & $\mathbf{1 0 5}$ & $\mathbf{5}$ & $\mathbf{1 5 5}$ & $\mathbf{3}$ & $\mathbf{7}$ \\
\hline
\end{tabular}

(1) teor de nitrogênio disponível devido, exclusivamente, ao fertilizante osmocote.

As avaliações dos parâmetros biométricos foram realizadas em 10 mudas de cada repetição, amostradas aleatoriamente, e foram iniciadas quando 100\% das plantas que cresceram com $50 \mathrm{~cm}^{3}$ de substrato apresentavam, no mínimo, 4 pares de folhas.

\subsection{Número de pares de folhas}

Refere-se ao número total de pares de folhas emitidas, desconsiderando as folhas cotiledonares, quando todas as mudas do experimento, independentemente dos tratamentos, apresentavam, no mínimo, 4 pares de folhas expandidas.

\subsection{Altura das plantas}

Para a determinação da altura $(\mathrm{cm})$ foi efetuada a medida entre o nível do substrato, na região do colo da planta, e a inserção do último par de folhas expandidas. 


\subsection{Diâmetro do caule}

Esta variável foi determinada utilizando um paquímetro digital, obtendo-se as medidas (mm) na região localizada abaixo da inserção das folhas cotiledonares.

\subsection{Matéria seca da parte aérea e raízes}

A parte aérea (folhas e caule) e as raízes das plantas após serem coletadas e separadas, foram submetidas à secagem em estufa com circulação de ar forçada a $70^{\circ} \mathrm{C}$ durante 36 horas até a obtenção de massa constante. Após o resfriamento do material realizou-se a determinação da matéria seca (g) de cada parte da planta, utilizando uma balança de precisão.

\section{5 Área foliar total da planta}

Para a obtenção da área foliar total da planta $\left(\mathrm{cm}^{2}\right)$ foi utilizado o processador de imagem digital LI-COR modelo 3100, conforme metodologia descrita em Tavares Júnior et al. (2002).

\section{6 Área foliar média}

A área foliar média $\left(\mathrm{AFm}, \mathrm{cm}^{2}\right)$ foi obtida pela relação ente a área foliar total (AFt) de cada planta e o número total de folhas (NF) das mesmas, conforme a expressão: $\mathrm{AFm}=\mathrm{AFt} / \mathrm{NF}$.

\section{7 Área foliar do $1^{0}$ par de folhas}

Esta variável foi determinada no primeiro par de folhas $\left(\mathrm{cm}^{2}\right)$ quando as plantas apresentavam o $2^{\circ}$ par de folhas totalmente expandidas. Para a obtenção da área foliar inicial ( $1^{\circ}$ par de folhas) foi utilizado o método proposto por Barros et al. (1973), não destrutivo, conforme descrito em Tavares Jr et al. (2002). A determinação desta variável foi realizada devido a correlação verificada entre a área das folhas cotiledonares e o diâmetro do caule das mudas de café (Favarin et al., 2003). 


\subsection{Comprimento e superfície de raízes}

As determinações das variáveis comprimento $(\mathrm{m})$ e superfície radicular $\left(\mathrm{cm}^{2}\right)$ foram realizadas por meio da captura de imagens com scanner de mesa e processadas pelo software SIARCS 3.0, desenvolvido pela EMBRAPA-CNPDIA, conforme metodologia descrita por Jorge (1996) e Cruvinel et al. (1996). As raízes após a lavagem, para a retirada das partículas de substrato, e secagem em estufa, foram dispostas sobre o scanner e separadas por classe de diâmetro com o auxílio de tesoura e pinça. Este procedimento foi adotado para que não ocorresse o sombreamento das raízes finas pelas raízes grossas, implicando em erro experimental na determinação destas variáveis.

\subsection{Tempo de formação da muda}

O tempo de formação da muda foi determinado a partir do transplantio das plântulas até o momento em que $100 \%$ das plantas apresentavam o $4^{\circ}$ par de folhas expandidas.

\subsection{Estabilidade do conjunto muda-substrato}

As mudas, no final do experimento, após o corte da parte aérea, foram submetidas a um teste vibratório para avaliar a desagregação, com base na quantidade de material esboroado. A finalidade deste teste foi estimar a estabilidade, ao manuseio, do conjunto muda-substrato. Para isso foram utilizadas três plantas por parcela, totalizando 12 plantas por tratamento, com quatro repetições. As mudas foram acondicionadas em garrafas de plástico com $10 \mathrm{~cm}$ de diâmetro, adaptadas a uma mesa vibratória (1750 rpm), permanecendo em movimento por 60 segundos. Esta operação foi repetida cinco vezes ( 5 ciclos) e ao final de cada ciclo de 60" de vibração, o material desprendido era recolhido e determinada a massa de substrato desagregado.

Os resultados obtidos de todos os parâmetros avaliados, exceto o tempo de formação da muda, foram submetidos à análise de variância e ao ser constatada a significância pelo teste $\mathrm{F}$, comparou-se a média dos tratamentos por meio do teste Tukey a 1 e $5 \%$ de probabilidade. 


\section{RESULTADOS E DISCUSSÃO}

O número de pares de folhas variou significativamente $(\mathrm{p}<0,01)$ em razão do volume e granulometria do substrato (Tabela 6). As plantas que se desenvolveram nos recipientes com $200 \mathrm{~cm}^{3}$ de substrato apresentaram o maior número de pares de folhas (6,45 pares de folhas), seguidas pelas plantas conduzidas em tubetes com $120 \mathrm{~cm}^{3}$ de substrato $(5,72$ pares de folhas) e, por último, as plantas que cresceram nos tubetes contendo $50 \mathrm{~cm}^{3}$ de substrato (4,87 pares de folhas). De acordo com os resultados a mistura, com base em volume, de 50\% do substrato comercial na granulometria original (SC) com 50\% do substrato comercial finamente moído (SCM), proporcionou crescimento superior às plantas (5,88 pares de folhas), não havendo diferença entre as mudas que cresceram no substrato na granulometria comercial $(5,58$ pares de folhas) e no substrato comercial finamente moído (5,57 pares de folhas).

Tabela 6. Médias do número de pares de folhas das mudas de café em razão do volume $\left(50,120\right.$ e $\left.200 \mathrm{~cm}^{3}\right)$ e granulometria do substrato $(100 \% \mathrm{SC}, 100 \% \mathrm{SCM}$ e $50 \% \mathrm{SC}+50 \% \mathrm{SCM})$

\begin{tabular}{lcccccc}
\hline \multirow{2}{*}{ Parâmetro } & \multicolumn{3}{c}{ Volume de substrato } & \multicolumn{3}{c}{ Granulometria do substrato } \\
& $50 \mathrm{~cm}^{3}$ & $120 \mathrm{~cm}^{3}$ & $200 \mathrm{~cm}^{3}$ & $\mathrm{SC}$ & $\mathrm{SCM}$ & SC+SCM \\
\hline $\mathrm{N}^{\mathrm{o}}$ pares folhas & $4,87 \mathrm{c}$ & $5,72 \mathrm{~b}$ & $6,45 \mathrm{a}$ & $5,58 \mathrm{~b}$ & $5,57 \mathrm{~b}$ & $5,88 \mathrm{a}$ \\
Valor F & & $180,03 * *$ & & $9,10 * *$ & \\
DMS & \multicolumn{3}{c}{0,27} & & 0,27 & \\
\hline
\end{tabular}

Médias seguidas pelas mesmas letras não diferem entre si pelo teste Tukey a 1\% de probabilidade. 
O número de pares de folhas emitidas pelas mudas de café é um parâmetro utilizado para definir o manejo das mudas em condições de viveiro, tais como a transferência das mudas do "berçário" ao viveiro de condução, o início da sua aclimatação visando o plantio, bem como a época que as plantas estão aptas ao transplantio no campo.

Um aspecto importante relacionado com os lançamentos foliares é o tempo de formação da muda (Tabela 7). Neste trabalho, este parâmetro foi determinado a partir do transplantio das plântulas até quando as mudas apresentavam o quarto par de folhas totalmente expandidas. É extremamente vantajosa a emissão do maior o número de pares de folhas no menor período de tempo possível pois possibilita o plantio antecipado, aproveitando a estação chuvosa quando as condições climáticas são, normalmente, favoráveis ao pegamento e o crescimento inicial das plantas. A antecipação do plantio, aproveitando a maior parte do período chuvoso, aumenta a taxa de pegamento das plantas, e diminui, conseqüentemente, a demanda por replantio e o custo da implantação da lavoura.

Nos tratamentos em que foi utilizada a maior quantidade de substrato (V3G1, V3G2 e V3G3: $200 \mathrm{~cm}^{3}$ ) as plantas emitiram o $4^{\circ}$ par de folhas cerca de 40 dias antes daquelas que cresceram em recipiente com volume intermediário de substrato (V2G1, V2G2 e V2G3: $120 \mathrm{~cm}^{3}$ ) e, aproximadamente, 55 dias antes das plantas desenvolvidas nos menores recipientes (V1G1, V1G2 e V1G3: $50 \mathrm{~cm}^{3}$ ) (Tabela 7). Do exposto, verifica-se que o crescimento das plantas, avaliado por meio do número de lançamentos foliares (pares de folhas) correlacionou com a variável volume de substrato. Estes resultados corroboram os dados obtidos por Melo (1999), que trabalhou com volumes iguais a 50 e $120 \mathrm{~cm}^{3}$ de substrato comercial plantmax. Da mesma forma corroboram, em parte, os dados obtidos por Costa et al. (1993) segundo os quais a formação de muda em tubete antecipa a fase de viveiro, devido ao transplantio das plântulas no estádio de folhas cotiledonares expandidas ("orelha de onça"). No presente trabalho, constata-se que a antecipação na formação da muda deve-se, principalmente, ao uso de maior volume de substrato $\left(200 \mathrm{~cm}^{3}\right)$, alcançando o $4^{\circ}$ par de folhas em, aproximadamente, 2,7 meses (81 dias), comparado com 4,1 meses (124 dias) e 4,5 meses (134 dias) que as 
mudas demoraram para atingir o referido estádio, quando as mesmas cresceram em recipientes com 120 e $50 \mathrm{~cm}^{3}$ de substrato, respectivamente (Tabela 7).

Tabela 7. Tempo de formação (meses) da muda de café em razão do volume e granulometria do substrato

\begin{tabular}{clcc}
\hline Tratamentos & \multicolumn{1}{c}{$\begin{array}{c}\text { Volume e granulometria } \\
\text { do substrato }\end{array}$} & $\begin{array}{c}4^{\circ} \text { par de } \\
\text { folhas (dias) }\end{array}$ & $\begin{array}{c}\text { Formação muda } \\
\text { (meses) }\end{array}$ \\
\hline V1G1 & V1: $50 \mathrm{~cm}^{3}$ e G1: $100 \% \mathrm{SC}$ & 137 & 4,6 \\
V1G2 & V1: $50 \mathrm{~cm}^{3}$ e G2: $100 \% \mathrm{SCM}$ & 131 & 4,3 \\
V1G3 & V1: $50 \mathrm{~cm}^{3}$ e G3: $50 \% \mathrm{SC}+50 \% \mathrm{SCM}$ & 134 & 4,5 \\
Média (V1) & - & $\mathbf{1 3 4}$ & $\mathbf{4 , 5}$ \\
V2G1 & V2: $120 \mathrm{~cm}^{3}$ e G1: $100 \% \mathrm{SC}$ & 122 & 4,1 \\
V2G2 & V2: $120 \mathrm{~cm}^{3}$ e G2: $100 \% \mathrm{SCM}$ & 127 & 4,2 \\
V2G3 & V2: $120 \mathrm{~cm}^{3}$ e G3: $50 \% \mathrm{SC}+50 \% \mathrm{SCM}$ & 123 & 4,1 \\
Média (V2) & - & $\mathbf{1 2 4}$ & $\mathbf{4 , 1}$ \\
V3G1 & V3: $200 \mathrm{~cm}^{3}$ e G1: $100 \% \mathrm{SC}$ & 84 & 2,8 \\
V3G2 & V3: $200 \mathrm{~cm}^{3}$ e G2: $100 \% \mathrm{SCM}$ & 81 & 2,7 \\
V3G3 & V3: $200 \mathrm{~cm}^{3}$ e G3: $50 \% \mathrm{SC}+50 \% \mathrm{SCM}$ & 78 & 2,6 \\
Média (V3) & - & $\mathbf{8 1}$ & $\mathbf{2 , 7}$ \\
\hline
\end{tabular}

Para o parâmetro altura de plantas constatou-se significância a $1 \%$ de probabilidade apenas para a variável volume de substrato (Tabela 8). As plantas desenvolvidas nos tubetes com maior volume de substrato apresentaram altura superior (200 $\mathrm{cm}^{3}: 20,9 \mathrm{~cm}$ ), enquanto o menor porte foi verificado nas plantas dos recipientes de menor volume, ou seja, $50 \mathrm{~cm}^{3}$ de substrato $(14,5 \mathrm{~cm})$. A utilização de $120 \mathrm{~cm}^{3}$ de substrato proporcionou a formação de plantas com altura intermediária $(17,1 \mathrm{~cm})$ as quais diferem daquelas que se desenvolveram nos recipientes com $200 \mathrm{~cm}^{3}$ e $50 \mathrm{~cm}^{3}$ de substrato, respectivamente. 
Tabela 8. Médias da altura $(\mathrm{cm})$ das mudas de café em razão do volume $(50,120$ e 200 $\mathrm{cm}^{3}$ ) de substrato

\begin{tabular}{lccc}
\hline \multicolumn{1}{r}{ Parâmetro } & \multicolumn{3}{c}{ Volume de substrato } \\
& $50 \mathrm{~cm}^{3}$ & $120 \mathrm{~cm}^{3}$ & $200 \mathrm{~cm}^{3}$ \\
\hline Altura de plantas & $14,5 \mathrm{c}$ & $17,1 \mathrm{~b}$ & $20,9 \mathrm{a}$ \\
Valor F & & $139,55^{* *}$ & \\
DMS & & 1,24 & \\
\hline
\end{tabular}

Médias seguidas pelas mesmas letras não diferem entre si pelo teste Tukey a 1\% de probabilidade.

Os melhores resultados para a altura de plantas e número de pares de folha, constatadas nas plantas que se desenvolveram com maior quantidade de substrato (200 $\mathrm{cm}^{3}$ ), em relação às plantas com $120 \mathrm{~cm}^{3}$ e $50 \mathrm{~cm}^{3}$ de substrato devem-se, provavelmente, à maior área foliar do primeiro par de folhas (Tabela 12).

O crescimento vegetal depende dos processos fisiológicos como as divisões e expansões celulares, consumindo energia obtida por meio da respiração de carboidrato. Assim, pode-se admitir que as plantas que possuíam maior área do $1^{\circ}$ par de folhas (área foliar inicial), tinham à sua disposição, desde o inicio da formação, maior quantidade de açúcar a ser utilizado à produção de energia. Embora não tenha sido avaliada a quantidade de carboidrato nas partes da planta, esta afirmação é aceitável uma vez que as condições às plantas, como a água (irrigação), insolação e temperatura atmosférica (ambiente de viveiro) não foram limitantes à fotossíntese (síntese de carboidrato). A maior quantidade de nutrientes fornecidos às plantas e de espaço ao crescimento radicular devem, também, ter propiciado melhores condições às plantas. Entretanto, embora a disponibilidade de nutrientes seja maior nos recipientes com maior volume de substrato (Tabela 5), este fato não é suficiente para explicar o grande crescimento vegetativo da muda, pois os teores foliares de nutrientes nas plantas são semelhantes, independentemente do volume de substrato utilizado (Tabela 13). Por sua vez a maior disponibilidade de espaço ao crescimento das raízes é uma explicação plausível para o crescimento superior das plantas de café em recipiente com $200 \mathrm{~cm}^{3}$ de substrato. Uma 
explicação para tal é a interdependência entre a parte aérea e as raízes (feed back), em que, o crescimento destas depende do suprimento de carboidrato sintetizado nas folhas que é variável com a área foliar, a aeração, entrada de $\mathrm{O}_{2}$ e saída de $\mathrm{CO}_{2}$, e do espaço poroso à expansão radicular.

Desde o início do crescimento das mudas, embora não tenha sido avaliado, o maior recipiente $\left(200 \mathrm{~cm}^{3}\right)$ deve ter propiciado um crescimento superior da superfície radicular. A respiração de substância energética, como carboidrato, nas raízes, fornece energia que será utilizada nas divisões e expansões celulares, responsáveis tanto pelo crescimento radicular quanto à absorção ativa de nutrientes. Assim, o crescimento depende da capacidade de renovação do ar do substrato por meio da difusão de $\mathrm{O}_{2}$ para o interior e a saída de $\mathrm{CO}_{2}$, impedindo que ocorra acúmulo em nível tóxico às raízes. Embora não tenha sido avaliada a composição do ar do substrato, pode-se admitir que no tubete de menor volume $\left(50 \mathrm{~cm}^{3}\right)$ de substrato o preenchimento dos poros pelas raízes reduz, com maior antecedência, as condições adequadas de aeração às mesmas.

Os resultados deste trabalho não corroboram os dados obtidos por Melo (1999) que verificou crescimento semelhante das plantas, independentemente do volume utilizado, com 50 ou $120 \mathrm{~cm}^{3}$ de substrato. Campos (2002) estudando a qualidade das mudas de café formadas em tubetes com 50 e $120 \mathrm{~cm}^{3}$ de substrato, utilizando as cultivares Topázio e Acaiá, também não constataram diferença em relação à altura de plantas. Entretanto, Rezende et al. (1995) que também estudaram a influência do volume de substrato na formação de mudas de limoeiro "Cravo", observaram um aumento linear para o incremento em altura do porta-enxerto a medida que aumentou o volume de substrato. Os resultados do presente trabalho não corroboram, em parte, a afirmação de Spomer (1982), para quem há relação entre o volume de substrato e a quantidade de água e nutrientes absorvidos e, em conseqüência, sobre a taxa de crescimento das plantas. No presente trabalho, como já apresentado, verificou-se correlação entre o crescimento e o volume de substrato, sem comprovação, entretanto, que o mesmo se deve à quantidade de água e, tampouco, de nutrientes absorvidos, conforme justificativa apresentada pela maioria dos autores em trabalhos dessa natureza. Como pode ser deduzida dos teores de nutrientes encontrados nas plantas, apresentando concentração 
semelhante, independentemente do volume de substrato (Tabela 13). Assim, a disponibilidade de nutrientes não é a principal causa, neste experimento, da variação de crescimento das plantas.

Para o diâmetro do caule das mudas verificou-se diferença estatística a $1 \%$ de probabilidade para as variáveis volume e granulometria do substrato comercial (Tabela 9). Na interação entre as variáveis (volume e granulometria) também constatou-se efeito significativo $(\mathrm{p}<0,05)$ para o diâmetro do caule (Tabela 10).

Tabela 9. Médias do diâmetro do caule $(\mathrm{mm})$ das mudas de café em razão do volume $\left(50,120\right.$ e $\left.200 \mathrm{~cm}^{3}\right)$ e da granulometria do substrato $(100 \% \mathrm{SC}, 100 \% \mathrm{SCM}$ e $50 \% \mathrm{SC}+50 \% \mathrm{SCM})$

\begin{tabular}{lcccccc}
\hline \multirow{2}{*}{ Parâmetro } & \multicolumn{3}{c}{ Volume de substrato } & \multicolumn{3}{c}{ Granulometria do substrato } \\
& $50 \mathrm{~cm}^{3}$ & $120 \mathrm{~cm}^{3}$ & $200 \mathrm{~cm}^{3}$ & $\mathrm{SC}$ & $\mathrm{SCM}$ & SC+SCM \\
\hline Diâmetro do caule & $2,4 \mathrm{c}$ & $3,4 \mathrm{~b}$ & $3,8 \mathrm{a}$ & $3,1 \mathrm{~b}$ & $3,1 \mathrm{~b}$ & $3,4 \mathrm{a}$ \\
Valor F & \multicolumn{3}{c}{$288,25^{* *}$} & & & $14,79^{* *}$ \\
DMS & 0,18 & & 0,18 & \\
\end{tabular}

Médias seguidas pelas mesmas letras não diferem entre si pelo teste Tukey a $1 \%$ de probabilidade.

As plantas que cresceram e se desenvolveram nos tubetes com $200 \mathrm{~cm}^{3}$ de substrato apresentaram maior diâmetro de caule $(3,8 \mathrm{~mm})$, seguidas das plantas dos recipientes com $120 \mathrm{~cm}^{3}(3,4 \mathrm{~mm})$ e $50 \mathrm{~cm}^{3}$ de substrato $(2,4 \mathrm{~mm})$, respectivamente (Tabela 9).

O maior diâmetro do caule deve-se, provavelmente, ao aumento na quantidade das reservas carreadas das folhas (fonte de carboidrato) até esse órgão, estimulando a atividade do câmbio vascular, meristema secundário que nas dicotiledôneas, como o cafeeiro, é responsável pelo crescimento em espessura, por meio da formação e expansão de células em direção ao exterior do caule. Como discutido anteriormente, a disponibilidade de carboidrato depende da área foliar da planta (Tabela 12) onde é efetuada a fotossíntese e assumindo que não houve limitação a este processo em função 
dos demais fatores envolvidos como, água, $\mathrm{CO}_{2}$, insolação e temperatura (condição de viveiro), pode-se inferir que a quantidade de açúcar sintetizada correlaciona-se com o aumento da superfície foliar.

Do exposto, pode-se, também, admitir que as plantas que cresceram com maior volume de substrato, por apresentarem maior diâmetro, terão à sua disposição uma quantidade superior de reservas (carboidrato) para ser metabolizado na fase de crescimento inicial no campo. Portanto, plantas com esta característica (maior diâmetro de caule) são desejáveis, uma vez que a taxa fotossintética é nula no período subseqüente ao plantio, pois a respiração de carboidrato é superior a sua produção pela fotossíntese, devido ao estresse sofrido pelas mudas durante o plantio. Assim, as mudas com diâmetro mais espesso (maior reserva), tem maior probabilidade de sobreviver, diminuindo a necessidade de replantio e, obviamente, o custo de implantação da lavoura. Além disso, estas plantas podem reiniciar o crescimento em menor período de tempo, desde que não haja limitação hídrica, aproveitando a estação chuvosa. Considerando a diminuição no tempo de formação da muda e o plantio em época climaticamente favorável, principalmente em relação à precipitação pluvial, pode-se afirmar que é recomendável a produção de mudas de café em tubete de $200 \mathrm{~cm}^{3}$ de substrato. Estes resultados corroboram os dados obtidos por Rezende et al. (1995), que avaliaram o efeito do volume e doses de superfosfato simples na formação de mudas de limoeiro 'Cravo' e de acordo com os autores, houve aumento do diâmetro do caule nas plantas produzidas em recipientes com maior volume de substrato. Entretanto, no trabalho de Campos (2002), utilizando recipientes com volumes iguais a 50 e $120 \mathrm{~cm}^{3}$ de substrato, o autor não observou diferença para este parâmetro (diâmetro do caule) em mudas de café.

Com relação a variável granulometria do substrato (Tabela 9) constatou-se diferença $(\mathrm{p}<0,01)$ para o parâmetro diâmetro do caule somente nas plantas que foram estabelecidas na mistura formada pelo substrato comercial na granulometria original ( $50 \% \mathrm{SC})$ e parte desse substrato finamente moído (50\% SCM) $(3,4 \mathrm{~mm})$. Nas demais granulometrias, $100 \%$ de substrato comercial $(3,1 \mathrm{~mm})$ e $100 \%$ de substrato comercial finamente moído (3,1 mm) não se verificou diferença para o referido parâmetro. 
$\mathrm{Na}$ interação entre as variáveis volume e granulometria do substrato verificouse que as plantas apresentaram o menor diâmetro $(p<0,05)$ na combinação entre o recipiente com $50 \mathrm{~cm}^{3}$ de substrato e o uso do material na granulometria comercial (50 $\mathrm{cm}^{3}$ e $100 \% \mathrm{SC}$ : $2,1 \mathrm{~mm}$ ), seguida pelas plantas obtidas com a mesma quantidade de substrato na granulometria finamente moída $\left(50 \mathrm{~cm}^{3}\right.$ e $\left.100 \% \mathrm{SCM}: 2,3 \mathrm{~mm}\right)$. O maior diâmetro foi obtido nas mudas formadas na mistura granulométrica $\left(50 \mathrm{~cm}^{3}\right.$ e $50 \% \mathrm{SC}+$ 50\% SCM: $2,9 \mathrm{~mm}$ ) (Tabela 10). A mistura dos substratos $(50 \% \mathrm{SC}+50 \% \mathrm{SCM})$ proporcionou, provavelmente, melhorias nas condições físicas, principalmente em relação à aeração, quando foi empregado o menor recipiente $\left(50 \mathrm{~cm}^{3}\right)$. Nos demais volumes de substrato $\left(120\right.$ e $\left.200 \mathrm{~cm}^{3}\right)$ não foram observadas variações para o diâmetro do caule em razão da granulometria propiciadas pelas diferentes composições de substrato.

Tabela 10. Médias do diâmetro do caule $(\mathrm{mm})$ das mudas de café em razão da interação entre as variáveis volume e granulometria do substrato

\begin{tabular}{cccc}
\hline Volume de & \multicolumn{3}{c}{ Granulometria do substrato } \\
substrato & $100 \% \mathrm{SC}$ & $100 \% \mathrm{SCM}$ & $50 \% \mathrm{SC}+50 \% \mathrm{SCM}$ \\
\hline $50 \mathrm{~cm}^{3}$ & $2,1 \mathrm{cC}$ & $2,3 \mathrm{cB}$ & $2,9 \mathrm{bA}$ \\
$120 \mathrm{~cm}^{3}$ & $3,4 \mathrm{bA}$ & $3,3 \mathrm{bA}$ & $3,5 \mathrm{aA}$ \\
$200 \mathrm{~cm}^{3}$ & $3,8 \mathrm{aA}$ & $3,8 \mathrm{aA}$ & $3,7 \mathrm{aA}$ \\
Valor F & & $10,33 *$ & \\
DMS & & 0,25 & \\
\hline
\end{tabular}

Médias seguidas pelas mesmas letras minúsculas na coluna e maiúsculas na linha, não diferem entre si pelo teste Tukey a 5\% de probabilidade.

Destaca-se, também, que houve interação entre todos os volumes de substrato avaliados $\left(50,120\right.$ e $\left.200 \mathrm{~cm}^{3}\right)$ e o uso de substrato na granulometria comercial $(100 \%$ SC) e na granulometria finamente moída (100\% SCM). As plantas que foram conduzidas nas condições dos tratamentos V3G1 $\left(200 \mathrm{~cm}^{3}\right.$ e 100\% SC: $\left.3,8 \mathrm{~mm}\right)$ apresentaram maior diâmetro do caule, seguidas das plantas dos tratamentos V2G1 (120 
$\mathrm{cm}^{3}$ e $\left.100 \% \mathrm{SC}: 3,4 \mathrm{~mm}\right)$ e, finalmente, das plantas dos tratamentos V1G1 $\left(50 \mathrm{~cm}^{3}\right.$ e 100\% SC: 2,1 mm). A mesma tendência foi observada nas plantas dos tratamentos V3G2 $\left(200 \mathrm{~cm}^{3}\right.$ e $\left.100 \% \mathrm{SCM}: 3,8 \mathrm{~mm}\right)$, as quais foram superiores às plantas dos tratamentos V2G2 (120 $\mathrm{cm}^{3}$ e $100 \%$ SCM: $\left.3,3 \mathrm{~mm}\right)$ e V1G2 $\left(50 \mathrm{~cm}^{3}\right.$ e $100 \%$ SCM: 2,3 $\mathrm{mm})$, respectivamente. Para a mistura entre as granulometrias $(50 \% \mathrm{SC}+50 \% \mathrm{SCM})$ verificou-se diferença somente nas plantas que cresceram no menor volume de substrato $\left(50 \mathrm{~cm}^{3}\right.$ e $\left.50 \% \mathrm{SC}+50 \% \mathrm{SCM}: 2,9 \mathrm{~mm}\right)$, com diâmetro do caule inferior às plantas dos tratamentos V2G3 $\left(120 \mathrm{~cm}^{3}\right.$ e $\left.50 \% \mathrm{SC}+50 \% \mathrm{SCM}: 3,5 \mathrm{~mm}\right)$ e V3G3 $\left(200 \mathrm{~cm}^{3}\right.$ e $50 \%$ $\mathrm{SC}+50 \% \mathrm{SCM}: 3,7 \mathrm{~mm}$ ) as quais apresentaram comportamento semelhante. Toledo (1992) observou maiores valores para o diâmetro do caule em mudas de citrus, quando utilizou substrato contendo maior quantidade de húmus de minhoca. Os substratos testados pelo autor variavam as proporções entre os componentes como a terra de subsolo, húmus de minhoca e areia.

A matéria seca da parte aérea e das raízes das mudas de café diferiu significativamente $(p<0,01)$ em razão da variável volume de substrato, enquanto para a variável granulometria houve, também, diferença a $1 \%$ de probabilidade somente para o parâmetro matéria seca da parte aérea (Tabela 11).

A maior quantidade de matéria seca da parte aérea e das raízes, nessa ordem, foi obtida nas plantas desenvolvidas com maior volume de substrato $\left(200 \mathrm{~cm}^{3}: 2,09 \mathrm{~g}\right.$ e 0,90 $\mathrm{g})$, seguidas das plantas que cresceram em tubetes com $120 \mathrm{~cm}^{3}(1,50 \mathrm{~g} \mathrm{e} 0,77 \mathrm{~g})$ e 50 $\mathrm{cm}^{3}$ de substrato $(0,89 \mathrm{~g}$ e $0,46 \mathrm{~g})$, respectivamente. Estes resultados podem ser explicados com base nos resultados que influenciam a matéria seca vegetal, ou seja, o maior número de pares de folhas (Tabela 6), a maior altura das plantas (Tabela 8), o aumento do diâmetro do caule (Tabela 9), a grande superfície foliar (Tabela 12), bem como do próprio sistema radicular como o comprimento e a superfície raízes das plantas (Tabela 15).

As plantas estabelecidas nos recipientes com $200 \mathrm{~cm}^{3}$ de substrato apresentaram as maiores quantidades de matéria seca da parte aérea, da ordem de $39,33 \%$ e $134,83 \%$ em relação aos resultados obtidos nas plantas formadas com $120 \mathrm{~cm}^{3}$ e $50 \mathrm{~cm}^{3}$ de substrato, respectivamente (Tabela 11). Estes resultados corroboram os dados obtidos por 
Vianna (1964), Godoy Júnior (1965), Silveira et al. (1973), Besagoitia (1980) e Melo (1999), segundo os quais a utilização de maior volume de substrato resulta na formação de mudas vigorosas. No trabalho realizado por Melo (1999), avaliando dois tipos de tubetes na produção de mudas de café (50 e $120 \mathrm{~cm}^{3}$ ), o autor verificou que o aumento da matéria seca da parte aérea das mudas correlacionou de forma quadrática com a época de amostragem e o volume de substrato.

Tabela 11. Médias da matéria seca da parte aérea e das raízes (g) das mudas de café em razão do volume $\left(50,120\right.$ e $\left.200 \mathrm{~cm}^{3}\right)$ e da granulometria do substrato $(100 \%$ $\mathrm{SC}, 100 \% \mathrm{SCM}$ e $50 \% \mathrm{SC}+50 \% \mathrm{SCM})$

\begin{tabular}{|c|c|c|c|c|c|c|}
\hline \multirow{2}{*}{ Parâmetros } & \multicolumn{3}{|c|}{ Volume de substrato } & \multicolumn{3}{|c|}{ Granulometria do substrato } \\
\hline & $50 \mathrm{~cm}^{3}$ & $120 \mathrm{~cm}^{3}$ & $200 \mathrm{~cm}^{3}$ & $\mathrm{SC}$ & $\mathrm{SCM}$ & $\mathrm{SC}+\mathrm{SCM}$ \\
\hline Matéria seca aérea & $0,89 \mathrm{c}$ & $1,50 \mathrm{~b}$ & $2,09 \mathrm{a}$ & $1,37 b$ & $1,41 b$ & $1,70 \mathrm{a}$ \\
\hline Valor F & & $237,62 * *$ & & & $21,89 * *$ & \\
\hline DMS & & 0,18 & & & 0,18 & \\
\hline Matéria seca raízes & $0,46 \mathrm{c}$ & $0,77 b$ & $0,90 \mathrm{a}$ & - & - & - \\
\hline Valor F & & $121,27 * *$ & & & - & \\
\hline DMS & & 0,09 & & & - & \\
\hline
\end{tabular}

Médias seguidas pelas mesmas letras não diferem entre si pelo teste Tukey a 1\% de probabilidade.

A diferença para a matéria seca das raízes em função do volume do substrato, variável com o tamanho do tubete (Tabela 11), pode ser explicada pela disponibilidade de espaço poroso à expansão radicular e, em parte, à quantidade de nutrientes fornecida às plantas (Tabela 5). Estes resultados não corroboram os dados obtidos por Campos (2002), uma vez que o autor não constatou diferença para a matéria seca de raízes, quando avaliou o crescimento do cafeeiro em recipientes contendo 50 e $120 \mathrm{~cm}^{3}$ de substrato.

Assim como ocorreu com a variável volume do substrato, os resultados da matéria seca da parte aérea em função da granulometria (Tabela 11) também foram superiores devido a influência significativa dos parâmetros biométricos que afetam a 
mesma, conforme revelam os resultados encontrados para o número de pares de folhas (Tabela 6), diâmetro do caule (Tabela 9) e superfície foliar das plantas (Tabela 12).

Com relação a variável granulometria (Tabela 11) verificou-se que as plantas conduzidas no substrato constituído pela mistura, a base de volume, de $50 \%$ do substrato comercial (SC, granulometria original) e 50\% desse substrato finamente moído (SCM), apresentaram maior quantidade de matéria seca da parte aérea $(1,70 \mathrm{~g})$. Nas plantas desenvolvidas nas demais granulometrias (100\% SC e 100\% SCM), não se verificou influência na matéria seca da parte aérea.

A ausência de significância estatística para o parâmetro matéria seca de raízes em razão da variável granulometria é um indicativo de que as granulometrias dos substratos, de acordo com as composições granulométricas avaliadas neste experimento, não prejudicaram a aeração e a drenagem, condições necessárias ao crescimento radicular, mesmo quando foi utilizado o substrato finamente moído (100\% SCM). 
Tabela 12. Médias da área foliar total $\left(\mathrm{cm}^{2}\right)$, área foliar média $\left(\mathrm{cm}^{2}\right)$ e área foliar do $1^{\circ}$ par de folhas $\left(\mathrm{cm}^{2}\right)$ das mudas de café em razão do volume $(50,120$ e 200 $\left.\mathrm{cm}^{3}\right)$ e da granulometria do substrato $(100 \% \mathrm{SC}, 100 \% \mathrm{SCM}$ e $50 \% \mathrm{SC}+50 \%$ $\mathrm{SCM})$

\begin{tabular}{|c|c|c|c|c|c|c|}
\hline \multirow{2}{*}{ Parâmetros } & \multicolumn{3}{|c|}{ Volume de substrato } & \multicolumn{3}{|c|}{ Granulometria do substrato } \\
\hline & $50 \mathrm{~cm}^{3}$ & $120 \mathrm{~cm}^{3}$ & $200 \mathrm{~cm}^{3}$ & $\mathrm{SC}$ & SCM & $\mathrm{SC}+\mathrm{SCM}$ \\
\hline Área foliar total & $114,70 \mathrm{c}$ & $178,52 b$ & $233,19 a$ & $167,75 b$ & $171,58 b$ & $198,62 \mathrm{a}$ \\
\hline Valor F & & $212,28 * *$ & & & $14,23 * *$ & \\
\hline DMS & & 20,29 & & & 20,29 & \\
\hline Área foliar média & $23,55 \mathrm{c}$ & $31,10 b$ & $37,94 a$ & $29,40 b$ & $30,12 b$ & $33,08 \mathrm{a}$ \\
\hline Valor F & & $113,33 * *$ & & & $8,35 * *$ & \\
\hline DMS & & 3,08 & & & 3,08 & \\
\hline Área foliar $1^{\circ}$ par & $34,46 \mathrm{c}$ & $46,69 b$ & $52,24 \mathrm{a}$ & $43,88 b$ & $45,07 b$ & $48,44 a$ \\
\hline Valor F & & $246,19 * *$ & & & $11,57 * *$ & \\
\hline DMS & & 3,16 & & & 3,16 & \\
\hline
\end{tabular}

Médias seguidas pelas mesmas letras não diferem entre si pelo teste Tukey a 1\% de probabilidade.

Os resultados da área foliar total, área foliar média e área foliar do primeiro par de folhas das mudas de café, em razão das variáveis volume e granulometria do substrato estão apresentados na Tabela 12. De acordo com os resultados a utilização de $200 \mathrm{~cm}^{3}$ de substrato proporcionou a formação de mudas com maior área foliar total $\left(233,19 \mathrm{~cm}^{2}\right)$, área foliar média $\left(37,94 \mathrm{~cm}^{2}\right)$ e área do $1^{\circ}$ par de folhas $\left(52,24 \mathrm{~cm}^{2}\right)$. Na seqüência, esses parâmetros foram iguais a $178,52 \mathrm{~cm}^{2}$ (área foliar total), $31,10 \mathrm{~cm}^{2}$ (área foliar média) e $46,69 \mathrm{~cm}^{2}$ (área do $1^{\circ}$ par de folhas), em plantas conduzidas em recipientes com $120 \mathrm{~cm}^{3}$ de substrato. Nas plantas formadas com $50 \mathrm{~cm}^{3}$ de substrato obtiveram-se os menores valores para estes parâmetros: área foliar total $\left(114,70 \mathrm{~cm}^{2}\right)$, área foliar média $(23,55$ $\left.\mathrm{cm}^{2}\right)$ e área do $1^{\mathrm{o}}$ par de folhas $\left(34,46 \mathrm{~cm}^{2}\right)$.

As variações observadas nos parâmetros biométricos relativos ao crescimento vegetativo como número de pares de folhas (Tabela 6), altura das plantas (Tabela 8), 
diâmetro do caule (Tabela 9), matéria seca da parte aérea e das raízes (Tabela 11) e das áreas foliares média e total (Tabela 12), podem ser atribuídas, inicialmente, a maior área do $1^{\circ}$ par de folhas, uma vez que a concentração em nutrientes eram semelhantes (Tabela 13), independentemente do volume de substrato. Este resultado corrobora os dados obtidos por Favarin et al. (2003), os quais verificaram maior diâmetro do caule em plantas de café que possuíam maior superfície das folhas cotiledonares.

Como já discutido, na ausência de fatores limitantes como a disponibilidade de água, gás carbônico, insolação e temperatura foliar e atmosférica (condição de viveiro) pode-se supor que a maior área do primeiro par de folhas e, provavelmente, a expansão radicular exploram eficientemente os nutrientes disponíveis no substrato (Tabela 5) propiciando a formação de maior quantidade de carboidrato. $O$ aumento na disponibilidade de açúcar, fonte de energia logo na fase inicial da planta $\left(1^{\circ}\right.$ par de folhas), favoreceu o crescimento das mesmas, inclusive da área foliar subseqüente, como indicam os resultados destes parâmetros: área foliar total e área foliar média (Tabela 12). Em conseqüência, os demais parâmetros, número de pares de folhas, altura e diâmetro das plantas foram, também, beneficiados, conferindo às plantas crescimento vegetativo vigoroso.

A área foliar é um parâmetro importante no crescimento da planta, pois o processo fotossintético depende da interceptação da energia luminosa pelas folhas e, posterior, conversão em energia química na forma de carboidrato. Assim, dentro de limites, pode-se afirmar que a eficiência na conversão da energia luminosa em energia química por meio da fotossíntese depende da área foliar. Por sua vez, a eficiência fotossintética depende: (i) da insolação (Nasyrov, 1978), fator que não variou entre os tratamentos, (ii) da taxa fotossintética por unidade de área foliar e (iii) da interceptação da radiação solar. Tanto a taxa fotossintética quanto a interceptação da radiação dependem da arquitetura e da dimensão do sistema fotoassimilador (Leong, 1980; Tavares Jr. et al., 2003). No presente experimento, o fator que variou desde o início do crescimento das plantas foi o tamanho do sistema fotoassimilador, conforme indicam os valores verificados para a superfície foliar inicial ( $1^{\circ}$ par de folhas) (Tabela 12). Como a arquitetura do sistema fotoassimilador é uma característica da cultivar de café, este fator 
não afetou os resultados, uma vez que foi utilizada a mesma cultivar em todos os tratamentos. Ainda com relação a arquitetura foliar, ressalta-se que as plantas foram distribuídas alternadamente nas bandejas de maneira que não ocorreu competição por luz devido ao auto-sombreamento das plantas. Assim, pode-se esperar que a absorção e a conversão da radiação em energia química, pela fixação de $\mathrm{CO}_{2}$ em carboidrato, foi superior nas plantas com maior área foliar, explicando, dessa maneira, o grande crescimento vegetativo, como pode ser visualizado na Figura 3 (plantas não destruídas durante as avaliações do experimento).

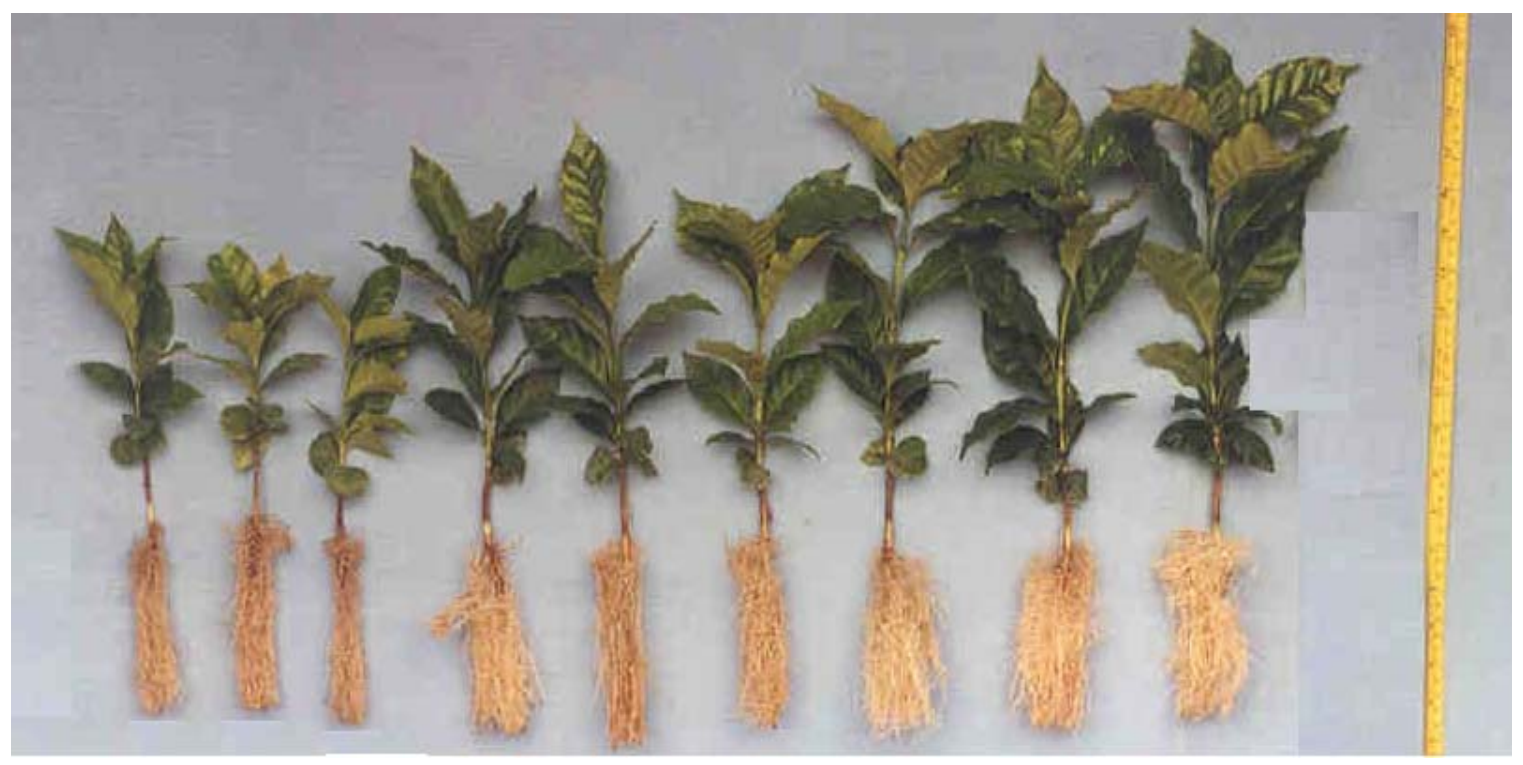

Figura 3 - Crescimento vegetativo das mudas de café formadas com 50, 120 e $200 \mathrm{~cm}^{3}$ de substrato

A utilização da mistura formada pelo substrato comercial na granulometria original ( $50 \% \mathrm{SC}$ ) com parte desse substrato finamente moído (50\% SCM), favoreceu a formação de plantas com maior área foliar $\left(198,62 \mathrm{~cm}^{2}\right)$, diferindo das plantas nas demais granulometrias (100\% SC e 100\% SCM) (Tabela 12). A área foliar média e do $1^{\circ}$ par de folhas das plantas conduzidas na referida mistura (50\% SC + 50\% SCM: 33,08 e 48,44 $\mathrm{cm}^{2}$ ) diferiram em relação às plantas que cresceram na granulometria comercial finamente moída (100\% SCM: 30,12 e $\left.45,07 \mathrm{~cm}^{2}\right)$ e na granulometria comercial $(100 \%$ 
SC: 29,40 e 43,88 $\mathrm{cm}^{2}$ ) (Tabela 12). Estes parâmetros (área foliar total, área foliar média e área do $1^{\circ}$ par de folhas) não diferiram entre si, comparando as plantas estabelecidas no substrato constituído a base de partículas grosseiras (100\% SC) e no material com predominância de partículas finas (100\% SCM).

$\mathrm{Na}$ interação entre as variáveis volume e granulometria do substrato detectou-se diferença significativa $(\mathrm{p}<0,05)$ para a área foliar total somente quando utilizou-se 120 $\mathrm{cm}^{3}$ de substrato. Nos demais volumes de substrato $\left(50\right.$ e $\left.200 \mathrm{~cm}^{3}\right)$ não houve influência da granulometria (Tabela 14).

De acordo com os dados obtidos, as plantas que cresceram com $120 \mathrm{~cm}^{3}$ de substrato apresentaram um ganho na área foliar total quando foi utilizada a mistura granulométrica constituída por $50 \%$ de substrato na granulometria comercial (SC) e 50\% desse substrato finamente moído (SCM) (Tabela 14).

Tabela 13. Concentração de nutrientes na folhas das plantas de café em razão dos tratamentos

\begin{tabular}{cccccccccccc}
\hline Tratamentos & $\mathrm{N}$ & $\mathrm{P}$ & $\mathrm{K}$ & $\mathrm{Ca}$ & $\mathrm{Mg}$ & $\mathrm{S}$ & $\mathrm{B}$ & $\mathrm{Cu}$ & $\mathrm{Fe}$ & $\mathrm{Mn}$ & $\mathrm{Zn}$ \\
\hline & \multicolumn{6}{c}{$\mathrm{g} \mathrm{kg}^{-1}$} \\
V1G1 & 16,5 & 1,6 & 21,7 & 11,9 & 3,8 & 2,1 & 66 & 1643 & 2480 & 146 & 25 \\
V1G2 & 14,9 & 1,4 & 18,4 & 11,3 & 3,5 & 1,7 & 56 & 1811 & 1980 & 130 & 22 \\
V1G3 & 16,2 & 1,6 & 20,8 & 11,0 & 3,6 & 1,8 & 55 & 1482 & 1804 & 144 & 26 \\
Média (V1) & $\mathbf{1 5 , 9}$ & $\mathbf{1 , 5}$ & $\mathbf{2 0 , 3}$ & $\mathbf{1 1 , 4}$ & $\mathbf{3 , 6}$ & $\mathbf{1 , 9}$ & $\mathbf{5 9}$ & $\mathbf{1 6 4 5}$ & $\mathbf{2 0 8 8}$ & $\mathbf{1 4 0}$ & $\mathbf{2 4}$ \\
V2G1 & 14,2 & 1,3 & 22,3 & 11,6 & 3,4 & 1,4 & 60 & 1644 & 1900 & 117 & 23 \\
V2G2 & 14,4 & 1,5 & 21,0 & 11,4 & 3,6 & 1,9 & 67 & 1923 & 1567 & 212 & 24 \\
V2G3 & 15,9 & 1,4 & 19,6 & 10,9 & 3,8 & 1,4 & 54 & 1702 & 1706 & 158 & 21 \\
Média (V2) & $\mathbf{1 4 , 8}$ & $\mathbf{1 , 4}$ & $\mathbf{2 1 , 0}$ & $\mathbf{1 1 , 3}$ & $\mathbf{3 , 6}$ & $\mathbf{1 , 6}$ & $\mathbf{6 0}$ & $\mathbf{1 7 5 6}$ & $\mathbf{1 7 2 4}$ & $\mathbf{1 6 2}$ & $\mathbf{2 3}$ \\
V3G1 & 15,7 & 1,4 & 18,4 & 10,9 & 3,7 & 1,8 & 72 & 1913 & 1467 & 136 & 24 \\
V3G2 & 15,3 & 1,6 & 19,8 & 11,3 & 3,9 & 1,7 & 76 & 1554 & 1720 & 169 & 20 \\
V3G3 & 15,4 & 1,8 & 20,8 & 10,8 & 3,8 & 2,4 & 68 & 1559 & 1871 & 184 & 20 \\
Média (V3) & $\mathbf{1 5 , 5}$ & $\mathbf{1 , 6}$ & $\mathbf{1 9 , 7}$ & $\mathbf{1 1 , 0}$ & $\mathbf{3 , 8}$ & $\mathbf{2 , 0}$ & $\mathbf{7 2}$ & $\mathbf{1 6 7 5}$ & $\mathbf{1 6 8 6}$ & $\mathbf{1 6 3}$ & $\mathbf{2 1}$ \\
\hline
\end{tabular}


Nas plantas estabelecidas em $50 \mathrm{~cm}^{3}$ de substrato, independentemente da granulometria, as mesmas tiveram a área foliar total prejudicada, provavelmente, pelo espaço reduzido à expansão radicular (Tabela 15$)$. Nestas condições $\left(50 \mathrm{~cm}^{3}\right)$ pode, também, ter sido afetada a absorção de nutrientes, em relação a absorção pelas plantas com maior superfície radicular, como nas mudas originadas com 120 e $200 \mathrm{~cm}^{3}$ de substrato. Assim, uma explicação para a semelhança na concentração de nutrientes nas plantas (Tabela 13), independentemente das quantidades de substratos, pode ser atribuída ao efeito de diluição, pois o crescimento das plantas (número de pares de folhas, altura e diâmetro das plantas) seguiu a mesma tendência, ou seja, foram superiores (diluindo os teores de nutrientes) do menor volume $\left(50 \mathrm{~cm}^{3}\right)$ para os maiores volumes de substratos, 120 e $200 \mathrm{~cm}^{3}$, respectivamente.

Tabela 14. Médias da área foliar total $\left(\mathrm{cm}^{2}\right)$ das mudas de café em razão da interação entre as variáveis volume e granulometria do substrato

\begin{tabular}{cccc}
\hline Volume de & & Granulometria do substrato \\
substrato & $100 \% \mathrm{SC}$ & $100 \% \mathrm{SCM}$ & $50 \% \mathrm{SC}+50 \% \mathrm{SCM}$ \\
\hline $50 \mathrm{~cm}^{3}$ & $110,09 \mathrm{cA}$ & $111,27 \mathrm{cA}$ & $122,86 \mathrm{cA}$ \\
$120 \mathrm{~cm}^{3}$ & $159,96 \mathrm{bB}$ & $161,22 \mathrm{bB}$ & $214,39 \mathrm{bA}$ \\
$200 \mathrm{~cm}^{3}$ & $233,20 \mathrm{aA}$ & $242,27 \mathrm{aA}$ & $258,62 \mathrm{aA}$ \\
Valor F & & $2,78^{*}$ & \\
DMS & & 27,27 &
\end{tabular}

Médias seguidas pelas mesmas letras minúsculas na coluna e maiúsculas na linha, não diferem entre si pelo teste Tukey a 5\% de probabilidade.

A superioridade da área foliar total nas plantas estabelecidas em $200 \mathrm{~cm}^{3} \mathrm{de}$ substrato comparado aos demais volumes, independentemente da granulometria (Tabela 14), resultou da condição favorável ao crescimento da planta, discutido anteriormente, como a área foliar inicial e o grande espaço poroso disponível às raízes.

Os resultados dos parâmetros comprimento e superfície de raízes do cafeeiro diferiram a $1 \%$ de probabilidade em razão da variável volume do substrato (Tabela 15). 
Com relação a variável granulometria foi constatada diferença estatística a $5 \%$ de probabilidade somente para o comprimento de raízes (Tabela 15).

De acordo com os resultados, os maiores valores para comprimento e superfície de raízes foram encontrados nas plantas formadas em $200 \mathrm{~cm}^{3}$ de substrato (CR: 31,43 m e SR: $166,27 \mathrm{~cm}^{2}$ ), seguidas pelas plantas conduzidas em $120 \mathrm{~cm}^{3}$ de substrato (CR: 21,0 m e SR: $114,10 \mathrm{~cm}^{2}$ ). Os piores resultados para estes parâmetros foram determinados nas plantas que cresceram em $50 \mathrm{~cm}^{3}$ de substrato (CR: $14,93 \mathrm{~m}$ e SR: $85,59 \mathrm{~cm}^{2}$ ).

Tabela 15. Médias do comprimento de raízes (m) e da superfície de raízes $\left(\mathrm{cm}^{2}\right)$ das mudas de café em razão do volume $\left(50,120\right.$ e $\left.200 \mathrm{~cm}^{3}\right)$ e da granulometria do substrato (100\% SC, $100 \%$ SCM e $50 \% \mathrm{SC}+50 \% \mathrm{SCM})$

\begin{tabular}{lcccccc}
\hline \multicolumn{1}{c}{ Parâmetros } & \multicolumn{3}{c}{ Volume de substrato } & \multicolumn{3}{c}{ Granulometria do substrato } \\
& $50 \mathrm{~cm}^{3}$ & $120 \mathrm{~cm}^{3}$ & $200 \mathrm{~cm}^{3}$ & $\mathrm{SC}$ & $\mathrm{SCM}$ & SC+SCM \\
\hline Comprimento raiz & $14,93 \mathrm{c}$ & $21,00 \mathrm{~b}$ & $31,43 \mathrm{a}$ & $20,97 \mathrm{~b}$ & $24,09 \mathrm{a}$ & $22,38 \mathrm{~b}$ \\
Valor F & & $93,64 * *$ & & & $3,28 *$ & \\
DMS & 3,92 & & 3,04 & - \\
Superfície raízes & $85,59 \mathrm{c}$ & $114,10 \mathrm{~b}$ & $166,27 \mathrm{a}$ & - & - & \\
Valor F & & $31,72 * *$ & & & \\
DMS & 33,05 & & & \\
\hline
\end{tabular}

Médias seguidas pelas mesmas letras não diferem entre si pelo teste Tukey a 1\% de probabilidade (volume de substrato) e a $5 \%$ de probabilidade (granulometria do substrato).

O grande desenvolvimento radicular como evidenciam os valores obtidos para os parâmetros comprimento e superfície de raízes pode ser atribuído: (i) ao maior saldo de carboidrato desde o início do crescimento das plantas, para ser alocado entre a parte aérea e as raízes, (ii) ao volume de poros devido ao maior espaço interno dos recipientes de 200 e $120 \mathrm{~cm}^{3}$ de capacidade, facilitando o crescimento radicular e a ocupação do espaço poroso, sem comprometimento da aeração e drenagem, condições indispensáveis à expansão radicular e (iii) à quantidade de nutrientes disponíveis às mudas que se 
formaram em 120 e $200 \mathrm{~cm}^{3}$ de substrato (Tabela 5). Esta última hipótese deve ser considerada com ressalvas, uma vez que a concentração dos nutrientes na parte aérea da planta foi semelhante, possivelmente, por efeito de diluição, não justificando ser a nutrição mineral, nas condições do experimento, o principal fator responsável pelo vigor e o crescimento vegetativo das plantas. Esta constatação não significa que a nutrição das plantas não seja importante, mas, tão somente, que as quantidades dos elementos nutritivos contidos no substrato (Tabela 5) foram suficientes para o desenvolvimento e a formação das mudas de café.

O comprimento das raízes das plantas foi influenciado também pela granulometria do substrato (Tabela 15), apresentando o maior valor deste parâmetro $(\mathrm{p}<0,05)$ nas plantas desenvolvidas no substrato comercial finamente moído $(100 \%$ $\mathrm{SCM})$.

Nas avaliações discutidas anteriormente, sempre que houve influência da variável granulometria do substrato, constatou, invariavelmente, a superioridade da mistura granulométrica $(50 \% \mathrm{SC}+50 \% \mathrm{SCM})$, constituída por $49,83 \%$ de partículas retidas nas peneiras $50(0,297 \mathrm{~mm})$ e $270(0,053 \mathrm{~mm})$. Esta observação foi verificada para os parâmetros biométricos como: número de pares de folhas (Tabela 6), diâmetro do caule da planta (Tabela 9), matéria seca da parte aérea (Tabela 11) e superfície foliar (Tabela 12). A única excessão deu-se com o parâmetro comprimento de raízes em que o crescimento foi superior nas plantas formadas no substrato com predomínio de partículas finas $(100 \% \mathrm{SCM})$, possuindo 62,24\% de partículas retidas nas peneiras $50(0,297 \mathrm{~mm}) \mathrm{e}$ $270(0,053 \mathrm{~mm})$. Nas demais granulometrias do substrato $(100 \% \mathrm{SC}$ e $50 \% \mathrm{SC}+50 \%$ SCM) não foi detectada diferença para este parâmetro (comprimento de raízes).

Com relação à estabilidade ao manuseio do conjunto muda-substrato, as avaliações simuladas por meio da quantidade de material esboroada, indicam que as mudas formadas em 50 e $120 \mathrm{~cm}^{3}$ de substrato não diferiram em relação a esta característica nos cinco ciclos de 60" de vibração em que o conjunto foi submetido (Tabela 16). 
Tabela 16. Médias da massa de material desagregado $(\mathrm{g})$ do conjunto muda-substrato ao final de cada ciclo de 60" de vibração em razão do volume de substrato

\begin{tabular}{cccccc}
\hline $\begin{array}{c}\text { Volume de substrato } \\
\left(\mathrm{cm}^{3}\right)\end{array}$ & $1^{\mathrm{o}}$ ciclo & $2^{\circ}$ ciclo & $3^{\circ}$ ciclo & $4^{\mathrm{o}}$ ciclo & $5^{\circ}$ ciclo \\
\hline 50 & $29,21 \mathrm{~b}$ & $29,59 \mathrm{~b}$ & $31,10 \mathrm{~b}$ & $32,10 \mathrm{~b}$ & $34,29 \mathrm{~b}$ \\
120 & $26,13 \mathrm{~b}$ & $30,45 \mathrm{~b}$ & $32,16 \mathrm{~b}$ & $32,74 \mathrm{~b}$ & $35,09 \mathrm{~b}$ \\
200 & $34,25 \mathrm{a}$ & $37,98 \mathrm{a}$ & $41,34 \mathrm{a}$ & $44,18 \mathrm{a}$ & $47,38 \mathrm{a}$ \\
Valor F & $4,50^{*}$ & $129,03 * *$ & $332,98^{* *}$ & $179,01^{* *}$ & $600,20 * *$ \\
DMS & 7,06 & 1,48 & 1,48 & 2,43 & 1,43 \\
\hline
\end{tabular}

Médias seguidas pelas mesmas letras nas colunas não diferem entre si pelo teste Tukey a $1 \%(* *)$ e $5 \%(*)$ de probabilidade.

As quantidades de materiais desagregados, independentemente dos ciclos de vibração, foram menores nos conjuntos muda-substrato formados nos recipientes de 50 e $120 \mathrm{~cm}^{3}$, comparativamente ao conjunto proveniente do recipiente de $200 \mathrm{~cm}^{3}$ de substrato. Embora a quantidade de raízes (Tabela 11) e o tamanho das mesmas (Tabela 15) fossem menores nas plantas que se desenvolveram em 50 e $120 \mathrm{~cm}^{3}$ de substrato, as mesmas propiciaram resistência superior ao esboroamento. Estes resultados podem ser indicativo de: (i) maior dificuldade operacional e risco de danos às raízes durante o plantio da muda formada em recipiente com maior quantidade de substrato $\left(200 \mathrm{~cm}^{3}\right)$ e (ii) o aumento da resistência ao esboroamento, observado nos conjuntos muda-substrato formados em 50 e $120 \mathrm{~cm}^{3}$ de substrato, pode significar maior aderência e, portanto, estabilidade ao manuseio do referido conjunto e ou representar, também, um aumento da dificuldade à expansão lateral das raízes e à sua capacidade para ocupar os espaços porosos do solo adjacente, confinando-as por um período maior a um pequeno volume de solo. Se esta hipótese for comprovada, isto implica em atraso na retomada do crescimento da muda no campo, afetando o estabelecimento e o crescimento das mesmas.

$\mathrm{Na}$ Figura 4 pode ser visualizado o comportamento da desagregação por meio da quantidade de massa de material esboroado ao final de cada ciclo de 60" de vibração do conjunto muda-substrato. Os valores não são acumulativos e evidenciam desempenho 
semelhante dos conjuntos oriundos dos menores recipientes (50 e $120 \mathrm{~cm}^{3}$ ), enquanto que o conjunto originado do recipiente com maior quantidade de substrato $\left(200 \mathrm{~cm}^{3}\right)$ observase uma tendência de aumentar a desagregação a medida que os mesmos (muda-substrato) são submetidos a sucessivos ciclos de vibração.

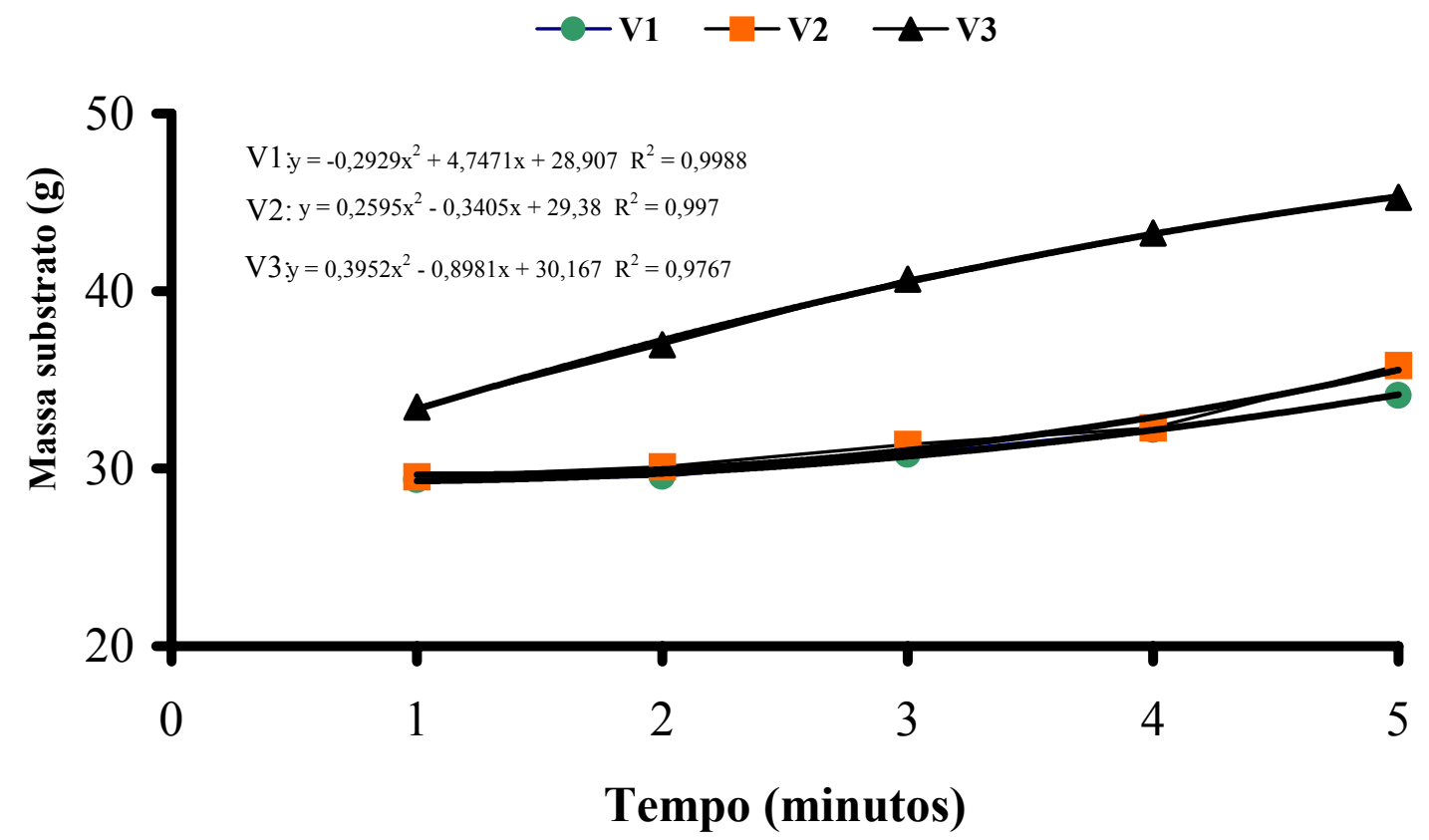

Figura 4 - Massa de material desagregado do conjunto muda-substrato ao final de cada ciclo de $60 "$ de vibração em razão do volume de substrato

A influência da granulometria sobre a estabilidade ao manuseio do conjunto muda-substrato pode ser verificada na Tabela 17. Os resultados indicam que no $1^{\circ}$ ciclo de 60" de vibração não há diferença entre os substratos, não possibilitando distinguir a influência da granulometria sobre a desagregação. Entretanto, a partir do $2^{\circ}$ ciclo de vibração pode-se diferenciar as diferentes estabilidades, ao manuseio, dos conjuntos, sendo maior quando os mesmos são provenientes da mistura granulométrica $(50 \% \mathrm{SC}+$ 
$50 \%$ SCM) e do substrato comercial na granulometria original (100\% SC), não havendo diferença entre ambos (Tabela 17).

A hipótese de que a diminuição da granulometria do material por meio da redução do tamanho das partículas do substrato, através da moagem do material, aumentaria a aderência das partículas com as raízes e, assim, a estabilidade, ao manuseio, do conjunto muda-substrato, não foi comprovada em sua plenitude. Tal fato pode ser verificado pelo aumento da quantidade de materiais esboroados que ocorreram no conjunto muda-substrato oriundo do material finamente moído (100\% SCM). A quantidade de material desagregado neste tratamento aumenta, substancialmente, com os sucessivos ciclos de vibração do conjunto (Figura 5).

Tabela 17. Médias da massa de material desagregado (g) do conjunto muda-substrato ao final de cada ciclo de 60 " de vibração em razão da granulometria do substrato

\begin{tabular}{cccccc}
\hline $\begin{array}{c}\text { Granulometria do } \\
\text { substrato }\end{array}$ & $1^{\circ}$ ciclo & $2^{\circ}$ ciclo & $3^{\circ}$ ciclo & $4^{\circ}$ ciclo & $5^{\circ}$ ciclo \\
\hline $100 \% \mathrm{SC}$ & $30,60 \mathrm{a}$ & $31,72 \mathrm{~b}$ & $33,20 \mathrm{~b}$ & $34,40 \mathrm{~b}$ & $36,59 \mathrm{~b}$ \\
$100 \% \mathrm{SCM}$ & $32,34 \mathrm{a}$ & $35,1 \mathrm{a}$ & $40,12 \mathrm{a}$ & $42,45 \mathrm{a}$ & $45,79 \mathrm{a}$ \\
$50 \% \mathrm{SC}+50 \% \mathrm{SCM}$ & $26,66 \mathrm{a}$ & $31,15 \mathrm{~b}$ & $31,26 \mathrm{c}$ & $32,15 \mathrm{c}$ & $34,38 \mathrm{c}$ \\
Valor F & $2,27^{*}$ & $28,30^{* *}$ & $227,88^{* *}$ & $113,65^{* *}$ & $408,35^{* *}$ \\
DMS & 7,06 & 1,48 & 1,48 & 2,43 & 1,43 \\
\hline
\end{tabular}

Médias seguidas pelas mesmas letras nas colunas não diferem entre si pelo teste Tukey a $1 \%(* *)$ e $5 \%(*)$ de probabilidade.

A partir do $3^{\circ}$ ciclo de vibração foi possível separar as diferentes estabilidades em razão das composições granulométricas, apresentando a menor estabilidade, nessa ordem, o conjunto muda-substrato proveniente da granulometria finamente moída (100\% SCM: 40,12 g), seguida pelo conjunto da granulometria comercial (100\% SC: 33,20 g) e, finalmente, o conjunto formado pela mistura granulométrica $(50 \% \mathrm{SC}+50 \% \mathrm{SCM}$ : 31,26 g). No $3^{\circ}, 4^{\circ}$ e $5^{\circ}$ ciclos de vibração a mistura granulométrica apresentou os menores valores relativos a quantidade de materiais desagregados, ou seja, conferiu maior 
estabilidade ao manuseio para o conjunto muda-substrato. Assim, pode-se afirmar que houve algum benéfico com a redução da granulometria do substrato, justificando, em parte a hipótese desse trabalho.

Para avaliar a interação entre as variáveis volume e granulometria do substrato foi apresentado a análise da quantidade de material desagregado no $3^{\circ}$ ciclo de vibração, quando foi possível distinguir, pela primeira vez, a influência das composições granulométricas em relação a estabilidade do conjunto muda-substrato (Tabela 18).

De acordo com os resultados apresentados na Tabela 18 constata-se que a combinação da menor quantidade de substrato $\left(50 \mathrm{~cm}^{3}\right)$ com a redução do tamanho das partículas aumentou a estabilidade ao manuseio, na seguinte ordem decrescente: mistura granulométrica $(50 \% \mathrm{SC}+50 \% \mathrm{SCM}: 28,75 \mathrm{~g})>$ substrato finamente moído $(100 \%$ SCM: $31,10 \mathrm{~g})>$ substrato na granulometria comercial (100\% SC: 33,63 g).

Tabela 18. Médias da massa de material desagregado $(\mathrm{g})$ do conjunto muda-substrato ao final do $3^{\circ}$ ciclo de $60 "$ de vibração em razão da interação das variáveis volume e granulometria do substrato

\begin{tabular}{cccc}
\hline Volume de & \multicolumn{3}{c}{ Granulometria do substrato } \\
substrato & $100 \% \mathrm{SC}$ & $100 \% \mathrm{SCM}$ & $50 \% \mathrm{SC}+50 \% \mathrm{SCM}$ \\
\hline $50 \mathrm{~cm}^{3}$ & $33,63 \mathrm{aA}$ & $31,10 \mathrm{bB}$ & $28,57 \mathrm{bC}$ \\
$120 \mathrm{~cm}^{3}$ & $32,07 \mathrm{aA}$ & $32,43 \mathrm{bA}$ & $31,97 \mathrm{aA}$ \\
$200 \mathrm{~cm}^{3}$ & $33,90 \mathrm{aB}$ & $56,83 \mathrm{aA}$ & $33,27 \mathrm{aB}$ \\
Valor F & & $213,26^{* *}$ & \\
DMS & & 3,37 & \\
\hline
\end{tabular}

Médias seguidas pelas mesmas letras minúsculas na coluna e maiúsculas na linha, não diferem entre si pelo teste Tukey a $1 \%$ de probabilidade.

Para o recipiente comumente utilizado na formação de mudas de café em tubete $\left(120 \mathrm{~cm}^{3}\right)$ não foi constatada influência da granulometria à estabilidade do conjunto muda-substrato (Tabela 18). Quando foi utilizado o maior volume de substrato $\left(200 \mathrm{~cm}^{3}\right)$ na granulometria finamente moída verificou-se maior desagregação $(56,83 \mathrm{~g})$, em relação 
às demais granulometrias (100\% SC: 33,90 g) e (50\% SC + 50\% SCM: $33,27 \mathrm{~g})$, não confirmando, em parte, a hipótese de que a redução do tamanho das partículas favoreceria a aderência destas com as raízes e, conseqüentemente, a estabilidade do conjunto mudasubstrato. Esta característica é desejável para reduzir o risco de injúria as raízes pela retirada da planta do tubete durante o plantio propriamente dito.

Como a aderência não aumentou em razão da diminuição do tamanho das partículas, como ocorreu ao conjunto formado no substrato com granulometria finamente moída (100\% SC), acabou facilitando o desprendimento das partículas mais finas durante a vibração do conjunto muda-substrato. Nestas condições, o maior crescimento do sistema radicular não foi suficiente para aumentar a aderência às partículas do substrato.

A metodologia utilizada no presente trabalho para estudar a estabilidade do conjunto muda-substrato merece novos estudos, com ajustes que se fazem necessários para ser melhor avaliada, como: (i) padronizar o diâmetro do recipiente onde é colocado o conjunto muda-substrato, de acordo com o diâmetro da muda, com a finalidade de uniformizar a intensidade dos impactos durante a vibração, (ii) ajustar a altura do conjunto muda-substrato no interior do recipiente de vibração, devido a variação na altura do referido conjunto, conforme o tipo de tubete utilizado e (iii) evitar danos ao conjunto muda-substrato durante a retirada do recipiente para o início do teste, pois a mesma intensificaria a desagregação, introduzindo erros na avaliação.

Como pode ser visualizado na Figura 5, embora os resultados da massa de material esboroado não sejam acumulativos entre os ciclos de vibração, percebe-se que, no início, os dados se equivalem e depois, a partir do $3^{\circ}$ ciclo de vibração, aumenta a desagregação conforme diminui a granulometria do material, como conseqüência, principalmente, pelo uso do maior recipiente. 
$\mathbf{G} 3 \Delta \mathrm{G} 2 \diamond \mathrm{G} 1$

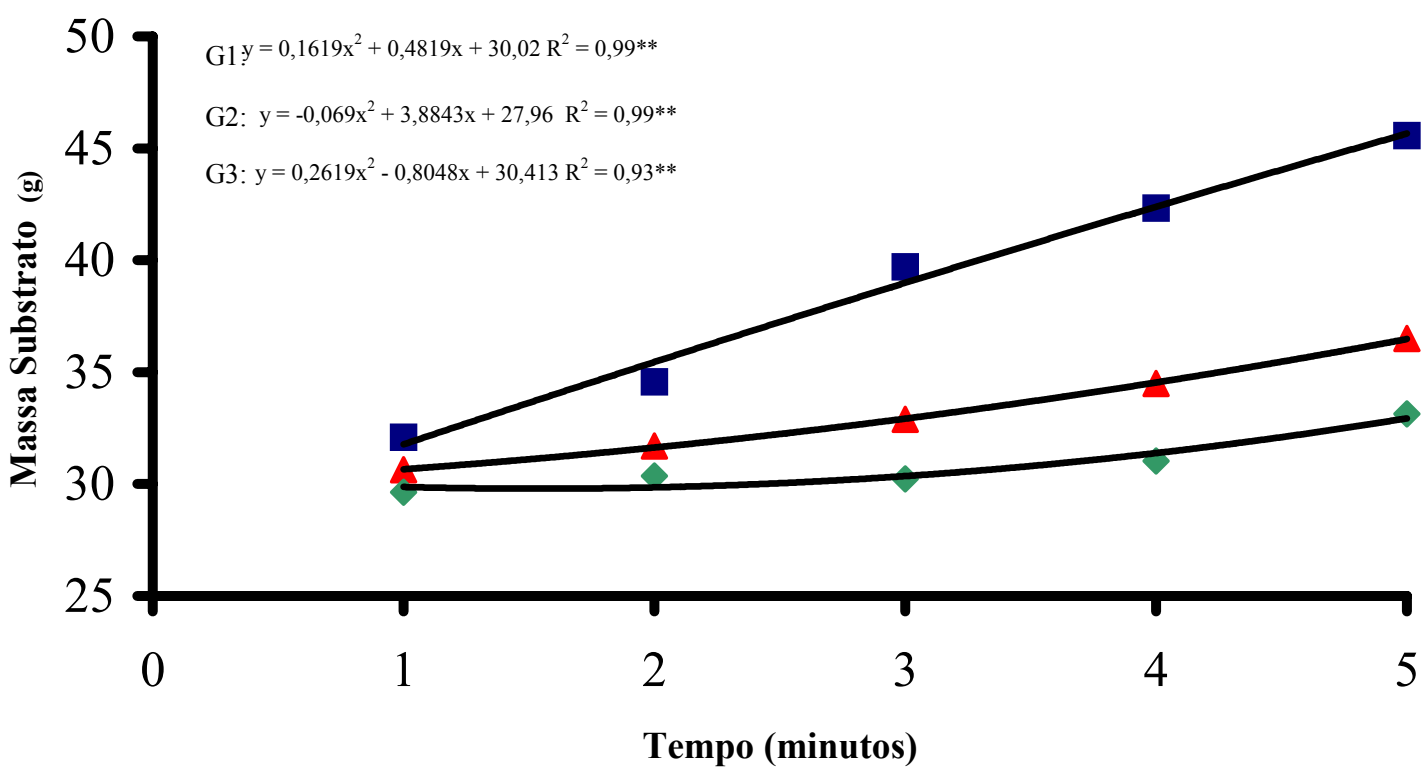

Figura 5 - Massa de material desagregado do conjunto muda-substrato ao final de cada ciclo de 60 " de vibração em razão da granulometria do substrato 


\section{CONCLUSÕES}

1. O crescimento das plantas depende do volume e da granulometria do substrato, sendo maior com a utilização de $200 \mathrm{~cm}^{3}$ de substrato e a diminuição da granulometria pela mistura, em partes iguais, do substrato finamente moído com o substrato comercial na granulometria original.

2. O tempo de formação das mudas correlacionou com o volume de substrato, demandando 134, 124 e 81 dias para a emissão do $4^{\circ}$ par de folhas, quando as plantas cresceram nos recipientes com 50, 120 e $200 \mathrm{~cm}^{3}$ de substrato, respectivamente.

3. A estabilidade ao manuseio do conjunto muda-substrato varia com o tamanho do recipiente, sendo maior nos tubetes com 50 e $120 \mathrm{~cm}^{3}$ de substrato, e a redução parcial da granulometria, pela mistura granulométrica, aumentou a aderência das partículas com as raízes e, portanto, a estabilidade do conjunto. 


\section{REFERÊNCIAS BIBLIOGRÁFICAS}

ANDRADE NETO, A.; MENDES, A.N.G.; GUIMARÃES, P.T.G.; PAIVA, C.P. Avaliação de substratos para produção de mudas de cafeeiro (Coffea arabica L.) em tubetes. In: CONGRESSO BRASILEIRO DE PESQUISAS CAFEEIRAS, 23., Manhuaçú, 1997. Anais. Rio de Janeiro: IBG, GERCA, 1997. p.192-194.

ANSORENA MINER, J. Sustratos: propriedades y caracterización. Madrid: MundiPrensa, 1994. 172p.

BANZATTO, D.A.; KRONKA, S.N. Experimentação Agrícola. Jaboticabal: Funep, 1995. 247p.

BEARDSELL, D.U.; NICHOLS, D.G.; JONES, D.L. Physical properties of nursery potting - mixtures. Scientia Horticulturae, v.11, p.1-8, 1979.

BESAGOITIA, M.R.C. Efecto del tamanõ de la bolsa em el desarrollo del cafetos cultirares 'Bourbon' y 'Pacas' en vivero. Resumens de Investigaciones en Café, v.3, p.71-72, nov. 1980 .

BOYLE, T.H.; CRAKER, L.E.; SIMON, J.E. Growing médium and fertilization regime influence growth essential oil content of rosemary. HortScience, v. 26, n.1, p.33-34, 1991. 
CAMPINHOS JUNIOR, E.; IKEMORI, Y.K. Introdução de nova técnica na produção de mudas de essências florestais. Silvicultura, v.8, n.28, p.226-228, jan./fev. 1983.

CAMPOS, K.P. Produção de mudas de cafeeiro (Coffea arábica L.) em diferentes espaçamentos, substratos, adubações e tamanhos de tubetes. Lavras, 2002. 90p. Dissertação (M.S.) - Universidade Federal de Lavras.

COSTA, A.C.M.; CORSI, T.; FAVORETO, A.J.; MOTTA FILHO, C.; BALUTI, F.F. Nova tecnologia de produção de mudas de café em tubetões. In: CONGRESSO BRASILEIRO DE PESQUISAS CAFEEIRAS, 18., Araxá, 1993. Anais. Rio de Janeiro: IBG, GERCA, 1993. p.93.

COUTINHO, C.J.; CARVALHO, C.M. O uso de vermiculita na produção de mudas florestais. In: ENCONTRO NACIONAL DE REFLORESTADORES, 7., Curitiba, 1983. Anais. Curitiba: s. ed., 1983. p.54-63.

CRUVINEL, P.E.; CRESTANA, S.; JORGE, L.A.C. Métodos e aplicações do processamento de imagens digitais. In: CRESTANA, S.; CRUVINEL, P.E.; MASCARENHAS, S.; BISCEGLI, C.I.; MARTIN NETO, L.; COLNAGO, L.A. (Ed.). Instrumentação agropecuária: contribuições no limiar do novo século. Brasília: EMBRAPA, SPI, 1996. cap.3, p. 91-151.

DANTAS, C.E.S. Crescimento e composição mineral de mudas de eucaliptos produzidas em composto orgânico em função da aplicação de fertilizantes minerais. Viçosa, 1992. 61p. Dissertação (M.S.) - Universidade Federal de Viçosa.

DEBOODT, M.; VERDONCK, O. The physical properties of the substrates in floriculture. Acta Horticulturae, n.26, p. 37-44, 1972.

DOUGLAS, J.S. Hidroponia: cultura sem terra. São Paulo: Nobel, 1987. 141p. 
FAVARIN, J.L.; COSTA, J.D.; NOVEMBRE, A.D.C.; FAZUOLI, L.C.; FAVARIN, M.G.G.V. Características da semente em relação ao potencial fisiológico e a qualidade de mudas de café tipo Arábica. In: SIMPÓSIO DE PESQUISA DOS CAFÉS DO BRASIL, III., Porto Seguro, 2003. Anais. Brasília: Embrapa, CBPD, 2003. p. 281.

FAVARIN, J.L.; CAMARGO, F.T. Influência do substrato na formação e desenvolvimento de mudas de café (Coffea arabica L.) na fase de viveiro. In: CONGRESSO BRASILEIRO DE PESQUISAS CAFEEIRAS, 25., Franca, 1999. Anais. Rio de Janeiro: IBG, GERCA, 1999. p. 99.

FAVORETO, A.J.; COSTA, A.C.M.; MOTTA FILHO, C.; BAlluT, F.F. Nova tecnologia para produção de mudas enxertadas de café. Marília: Cooperativa dos Cafeicultores da Região de Marília, 1992. 7p.

FAVORETO, A.J.; GUALBERTO, R.; OLIVEIRA, P.S.R.; RESENDE, F.V. Uso de fontes orgânicas e fertilizantes de liberação lenta na formação de mudas de café em sacos de polietileno. In: CONGRESSO BRASILEIRO DE PESQUISAS CAFEEIRAS, 24., Poços de Caldas, 1998. Anais. Rio de Janeiro: IBG, GERCA, 1998. p.144-145.

FILGUEIRA, F.A.R. Novo manual de olericultura; agrotecnologia moderna na produção e comercialização de hortaliças. Viçosa: Universidade Federal de Viçosa, 2000. 402p.

FNP CONSULTORIA \& COMÉRCIO. AGRIANUAL 2003:anuário estatístico da agricultura brasileira. São Paulo, 2002. p.208-219: Café.

GODOY JUNIOR, C. Café, mudas em recipientes de polietileno. Revista de Agricultura, v.40, n.1, p.161-166, 1965. 
GOMES, J.M.; COUTO, L.; PEREIRA, A.R. Uso de diferentes substratos na produção de mudas de Eucalyptus grandis em tubetes e em bandejas de isopor. Árvore, v.9, n.1, p.58-86, 1985.

GONÇALVES, J.C.; THOMAZIELlO, R.A. Produção de mudas de café. Campinas: Coordenadoria de Assistência Técnica Integral, 1970. 25p. (CATI. Boletim Técnico, $63)$.

GONÇAVES, A.J Substratos para produção de mudas de plantas ornamentais. In: MINAMI, K. (Ed.). Produção de mudas de alta qualidade em horticultura. São Paulo: Queiroz, 1995. p. 107-115.

GUIMARÃES, P.T.G.; ANDRADE NETO, A.; BELLINI JUNIOR, O.; ADÃO,W.A.; SILVA, E.M. A produção de mudas de cafeeiros em tubetes. Informe Agropecuário, v.19, n.193, p.98-109, 1998.

HARTMANN, H.T.; FLOCKER, W.J.; KOFRANEK, A.M. Plant science: growth, development and utilization of cultivated plants. New York: Prentice - Hall, 1981. $637 \mathrm{p}$.

INSTITUTO BRASILEIRO DO CAFÉ. Cultura do café no Brasil: pequeno manual de recomendações. Rio de Janeiro, 1986. 214p.

JORGE, L.A.C. Recomendações práticas para aquisição de imagens digitais analisadas através do SIARCS. São Carlos: EMBRAPA, CNPDIA, 1996. 54p. (Circular Técnica, 1/96).

LEONG, W. Canopy modification and this effects on the growth and yield of Hevea brasiliensis Muell. Ghent, 1980. 283p. Thesis (Ph.D.) - Faculty of Agriculture Sciences of Ghent. 
MARTINEZ, H. E. P.; BARBOSA, J. G. Substratos para hidroponia. Informe Agropecuário, v.20, n.200/201, p.81-89, 1999.

MELLO, A. C. G. Efeito de recipientes e substratos no comportamento silvicultural de plantas de Eucaliptos grandis Hill Ex Maiden e do Eucalyptos urophylla S. T. Blake. Piracicaba, 1989. 80p. Dissertação (Mestrado) - Escola Superior de Agricultura "Luiz de Queiroz”, Universidade de São Paulo.

MELO, B. Estudos sobre a produção de mudas de cafeeiro (Coffea arábica L.) em tubetes. 1999. p.119. Tese (Doutorado) - Universidade Federal de Lavras.

MELO, B.; MENDES, A.N.G.; GUIMARÃES, P.T.G. Doses crescentes de fertilizante de liberação lenta na produção de mudas de cafeeiro (Coffea arabica L.) em tubetes. In: CONGRESSO BRASILEIRO DE PESQUISAS CAFEEIRAS, 25., Franca, 1999. Anais. Rio de Janeiro: IBG, GERCA, 1999a. p.174-175.

MELO, B.; MENDES, A.N.G.; GUIMARÃES, P.T.G. Substratos, fontes e doses de $\mathrm{P}_{2} \mathrm{O}_{5}$ na produção de mudas de cafeeiro (Coffea arabica L.) em tubetes. In: CONGRESSO BRASILEIRO DE PESQUISAS CAFEEIRAS, 25., Franca, 1999. Anais. Rio de Janeiro: IBG, GERCA, 1999b. p.176-177.

MELO, B.; MENDES, A.N.G.; GUIMARÃES, P.T.G. Tamanhos de tubetes na produção de mudas de cafeeiro (Coffea arabica L.). In: CONGRESSO BRASILEIRO DE PESQUISAS CAFEEIRAS, 25., Franca, 1999. Anais. Rio de Janeiro: IBG, GERCA, 1999c. p.177-178.

MELO, B.; MENDES, A.N.G.; GUIMARÃES, P.T.G. Tipos de fertilizações e diferentes substratos na produção de mudas de cafeeiro (Coffea arabica L.) em tubetes. In: CONGRESSO BRASILEIRO DE PESQUISAS CAFEEIRAS, 25., Franca, 1999. Anais. Rio de Janeiro: IBG, GERCA, 1999d. p.178-179. 
MINAMI, K. Produção de mudas de alta qualidade em horticultura. São Paulo: Queiroz, 1995. 136p.

MORII, A.S.; GUIMARÃES, R.J.; MENDES, A.N.G.; DUTRA, M.R.; MONTEIRO, J.V.; PAIVA, L.C. Aplicação de granulados de solo na formação de mudas de cafeeiro. In: CONGRESSO BRASILEIRO DE PESQUISAS CAFEEIRAS, 23., Manhuaçú, 1997. Anais. Rio de Janeiro: IBG, GERCA, 1997. p.243-245.

NASYROV, Y.S. Genetic control of photosynthesis and improving of crop productivity. Annual Review of Plant Physiology, v.29, p.215-237, 1978.

OLIVEIRA, P.R.S.; GUALBERTO, R.; FAVORETO, A.J. Efeito do osmocote adicionado ao substrato plantmax na produção de mudas de café em tubetes. In: CONGRESSO BRASILEIRO DE PESQUISAS CAFEEIRAS, 21., Caxambú, 1995. Anais. Rio de Janeiro: IBG, GERCA, 1995. p.70-72.

ORTOLANI, L. L. A.; GONÇALVES, L.N.; GUIMARÃES, A.M.; OLIVEIRA, P.R.S.; RESENDE, F.V.; SILVA, R.F.; MOTTA, C.F.; BALUT, F.F.; FAVORETO, A.J. Comparação entre diversos fertilizantes e adições do condicionador físico de solo terra cottem em mudas em tubetes com substrato plantmax-café. In: CONGRESSO BRASILEIRO DE PESQUISAS CAFEEIRAS, 24., Poços de Caldas, 1998. Anais. Rio de Janeiro: IBG, GERCA, 1998. p.131-132.

PAIVA, C.P.; MENDES, A.N.G. Estudo de doses do fertilizante de liberação lenta "osmocote" na produção de mudas de cafeeiro (Coffea arabica L.) em tubetes. In: CONGRESSO BRASILEIRO DE PESQUISAS CAFEEIRAS, 24., Poços de Caldas, 1998. Anais. Rio de Janeiro: IBG, GERCA, 1998. p.196-197. 
PAIVA, C.P.; ANDRADE NETO, A.; MENDES, A.N.G.; GUIMARÃES, P.T.G. Estudo de tipos de fertilizantes osmocote na produção de mudas de cafeeiro (Coffea arabica L.) em tubetes. In: CONGRESSO BRASILEIRO DE PESQUISAS CAFEEIRAS, 23., Manhuaçú, 1997. Anais. Rio de Janeiro: IBG, GERCA, 1997. p.225-226.

PHIPPS, H. M. Influence of media on growth on survive all of container - grown seedling. In: NORTH AMERICAN CONTAINERIZER FOREST TREE SEEDLING SYMPOSIUM, Denver, 1974. Proceedings. Denver: Great Plains Agricultural Council, 1974. p. 398 - 400.

RESH, H.M. Hidroponic food production. 2.ed. Madrid: Mundi -Prensa, 1995. 318p.

REZENDE, L. P.; AMARAL, A. M.; CARVALHO, S. A.; SOBRINHO, F. S.; SOUZA, M. Volume de substrato e superfosfato simples na formação do limoeiro "cravo" em vasos. Ciência e Agrotecnologia, v.22, n.4, p.509-515, 1998.

SANTOS, L.P. Efeito de doses de nitrato de potássio e esterco de curral na composição do substrato para formação de mudas de cafeeiro (Coffea arabica L.). Lavras, 1993. 72p. Dissertação (M.S.) - Universidade Federal de Lavras.

SILVEIRA, A.J.da; SANTANA, D.P.; PEREIRA, M.L. Efeito do tamanho do saco plástico e do método de semeadura no desenvolvimento de mudas de café. Seiva, v.33, n.77, p.14-18, 1973.

SIMÕES, J. W. Problemática da produção de mudas em essências florestais. Piracicaba: IPEF, 1987. 29p. (IPEF. Serie Técnica, 4).

SPOMER, L. A. The effect of container soil volume on plant growth. HortScience, v.17, n.4, p.680-681, 1982. 
SPURR, S.H.; BARNES, B.V. Forest ecology. New York: The Ronald Press, 1973. $571 \mathrm{p}$.

STURION, J.A. Métodos de produção e técnicas de manejo que influenciam o padrão de qualidade de mudas florestais. Curitiba: EMBRAPA, URPFCS, 1981. 18p. (EMBRAPA. URPFCS. Documentos, 3).

TAVARES JUNIOR, J.E., FAVARIN, J.L., DOURADO NETO, D., MAIA, A. H.N.; FAZUOLI, L.C., BERNARDES, M.S. Análise comparativa de métodos de estimativa de área foliar em cafeeiro. Bragantia, v.61, n.2, p.199-203, 2002.

THEODORO, V.C.A.; CARVALHO, J.G.; ASSIS, M.P.; GUIMARÃES, R.J.; SILVA, E.B.; FERREIRA, L. Uso do vermicomposto na produção de mudas de cafeeiro (Coffea arabica L.). In: CONGRESSO BRASILEIRO DE PESQUISAS CAFEEIRAS, 23., Manhuaçú, 1997. Anais. Rio de Janeiro: IBG, GERCA, 1997. p.164-166.

THOMAZIELLO, R.A.; OLIVEIRA, E.G.; TOLEDO FILHO, J.A.; COSTA, T.E. Cultura do café. Campinas: Coordenadoria da Assistência Técnica Integral, 1996. 75p. (CATI. Boletim Técnico, 193).

TOLEDO, A.R.M. Efeito de substratos na produção de mudas de laranjeira (Citrus sinensis (L.) OSBECK cv. 'Pera Rio') em vaso. Lavras, 1982. 88p. Dissertação (M.S.) - Universidade Federal de Lavras.

VERDONCK, O. New developments in the use of graded perlite in horticultural substrates. Acta Horticulturae, n.150, p.575 - 581, 1983. 
VIANNA, A.C.C. Desenvolvimento de mudas de café em bolsas de polietileno. Ciência e Cultura, v.16, n.2, p.142-143, 1964.

WALTERS, W.E.; LEWELLLYN, W.; NESMITH, J. The chemical, physical and salinity characteristics of twenty seven soil media. Proceedings of the Florida State Horticultural Society, v.83, p.482-488, 1970. 